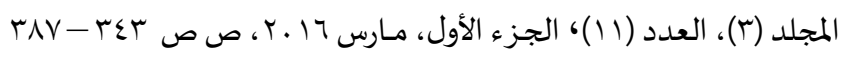

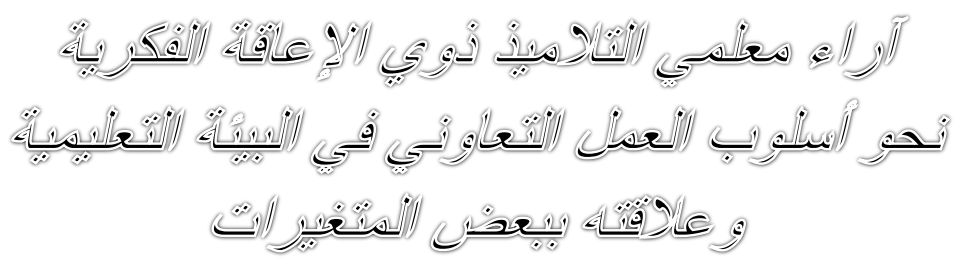

$$
\text { إعـداد }
$$

$$
\text { أ/ وضحسـى عـبل العتبيبـي }
$$

محاضرة بجامعة شقر اء - كلية التربية

قسم التربية الخاصة - مسار إعاقة فكرية

$$
\text { أ ـد/ أحدد بن عبدالعزيز التمبيهي }
$$

$$
\text { DOI: 10.12816/0023063 }
$$




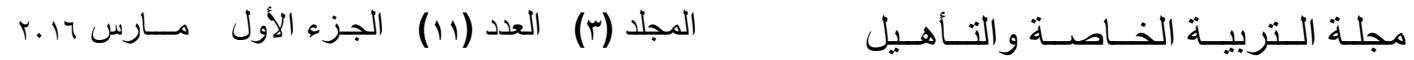

آراء معلمي التناميز ذوي الإعاقة الفكرية نحو أسلوب العدل التعاونسي في البيئة التعلبية و علاقته

إعـداد

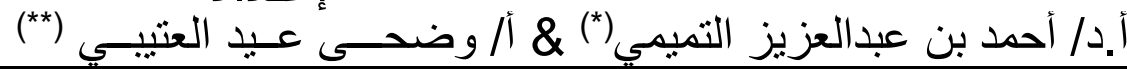

\section{ملنـ ص}

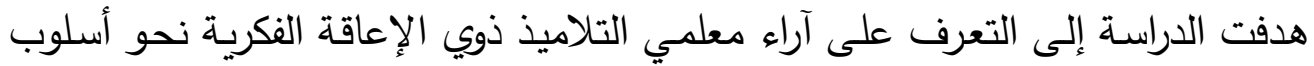

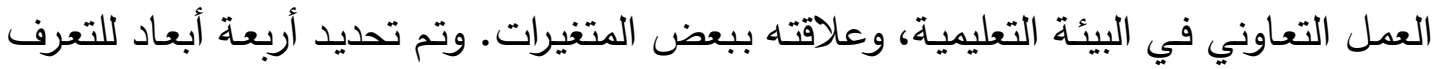

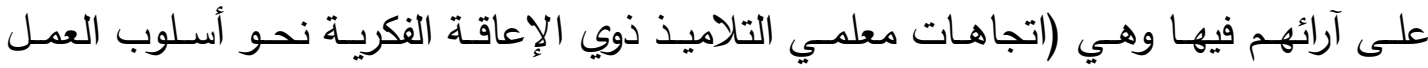
التعاوني, العناصر الأساسية اللازمة لإنجاح العمل التعاوني بين المعلمين, الكفايات الأساسية

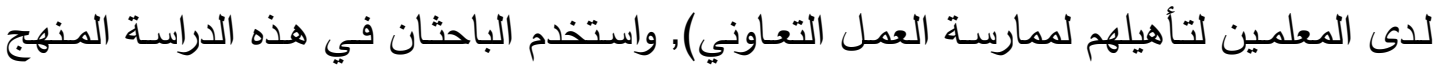

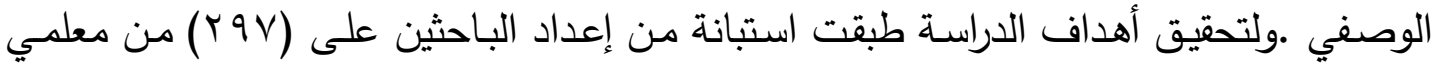

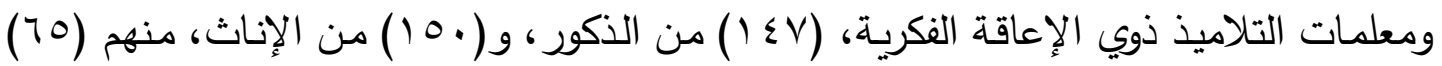

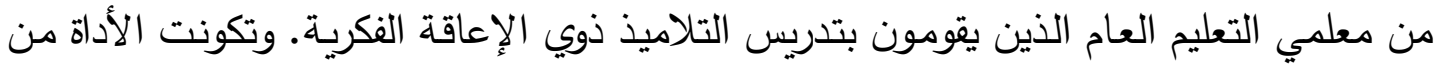

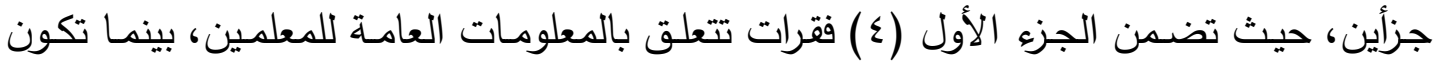

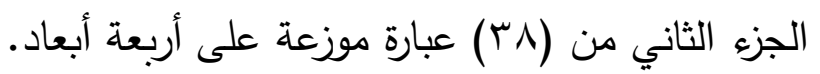
وأوضحت نتائج الدراسة ما يلي:

1- أن معظم أفراد الدراسة يحملون آراء وتوجهات إيجابية نحو أسلوب العمل التعاوني في

البيئة التعليمية على جميع أبعاد الإستبانة. r- أن معظمه كانت استجاباتهم مرتفعة على بعد الاتجاهات والعناصر الأساسية لإنجاح الإنهانه العمل التعاوني مقارنة بالبعدين الآخرين.

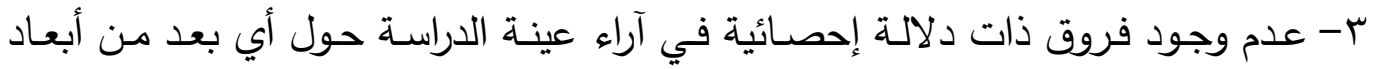

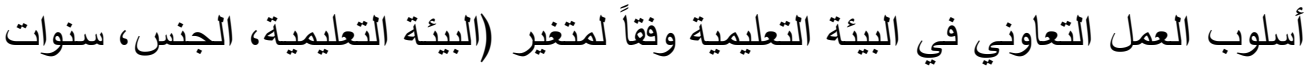
الخبرة).

ع- وجود فروق ذات دلالمة إحصـائية بين المعلمين حول بُعد العناصـر الأساسية اللازمـة

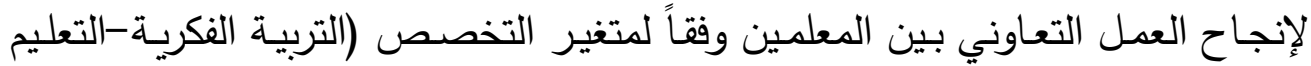

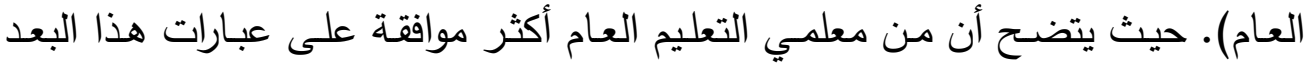
مقارنة بمعلمي التربية الفكرية. الكلمات المفتاحية: معلمي التلاميذ ذوي الإعاقة الفكرية, أسلوب العمل التعاوني, البيئة التعليمية. 


\section{Perspectives Students with Intellectual Disability Teachers On Collaborative work style at The Learning Environment and lts Relationship with Some Variables \\ Dr: Ahmad altamimi , wadha alotaibi Ahstract}

The present study aims at identifying the perspectives of the teachers of the intellectual disability students on the style of collaborative work in the learning environment, and its relationship with some variables. In order to achieve these objectives the Researcher has administered a questionnaire on (297) of teachers of students with intellectual disability ( (147) males and (150). and of them (65)) of the general education teachers who teach intellectual disability students. The questionnaire consists of two parts, the first of which includes (4) items related to the teachers' general knowledge, while the second part consists of (38) items distributed over four dimensions, the study concludes the following results:

1- most teachers hold positive views and trends towards the cooperative work method in the learning environment on all questionnaire dimensions.

2- The study has also concluded that most teachers replies were higher than the questionnaire dimensions, and the basic elements for successful collaborative work as contrasted with the other two dimensions.

3- study results have also shown no differences of statistical significance on the views related to the study samples for any of the dimensions related to the cooperative work method based on the variable of the educational environment ( like gender and years of experience ).

4- As for the variable related to the teachers' categories, there were differences of statistical significance among teachers - with respect to the dimension of the basic elements essential for the successful and collaborative work among teachers only based on their categories. It has become clear that general education teachers are more liable for consent to the items of this dimension than the teachers of the intellectual education. These results show how important the revival of the collaborative work is among teachers in the light of the basic elements essential for its success.

Key words: Intellectual Disabilities Teachers Perspective toward, Collaborative work style, The Educational Environment, Some Variables 
لقد حظي الأفراد ذوي الإعاقة في المملكة العربية السعودية باهتمام واضح تجلى في التي

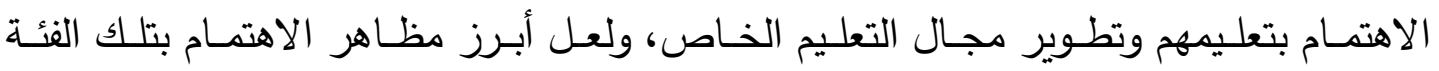

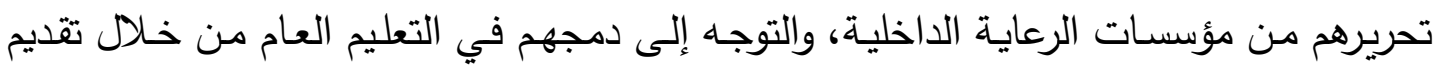

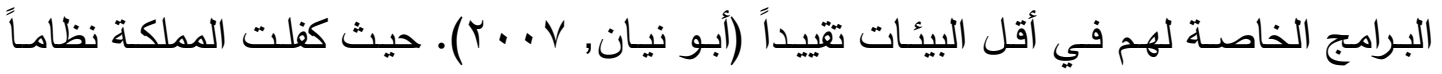

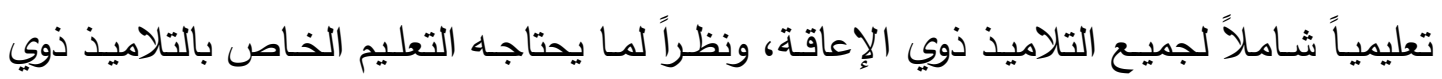

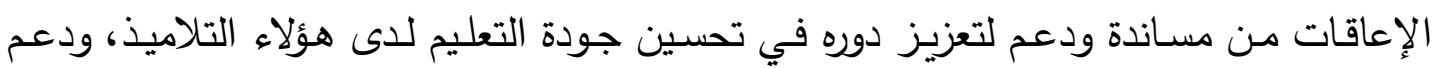

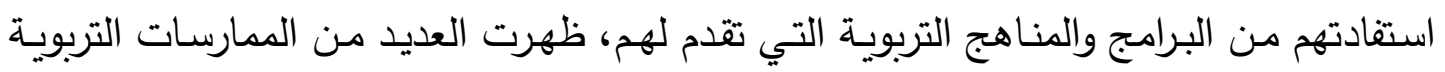
لتؤدي هذا الدور بفاعلية. إن عملية تعليم التلاميذ ذوي الإعاقة - وتحديداً الإعاقة الفكرية- الذين لا يتمكنون من

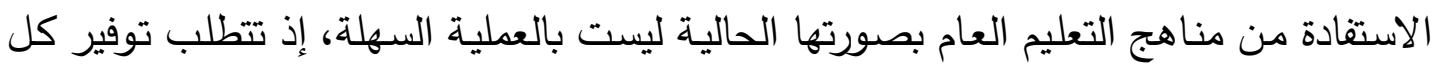

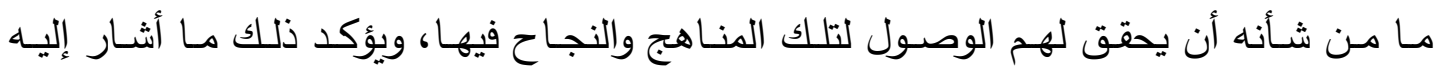
ماديجان وشروت (Madigan \& Schroth, 2011) بأن التعاون بين المعلمين في الفصول

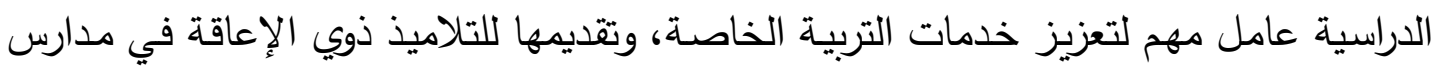
التعليم العام، مما يدعم نجاح العملية التعليمية لهؤلاء التلاميذ قدر الإمكان.

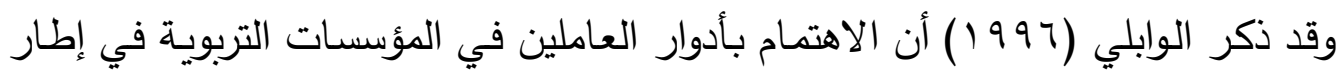
فريق عمل تعاوني ما هو إلا نموذج يهدف إلى تعليم التلاميذ ذوي الإعاقة وتأهيلهم بفاعلية؛

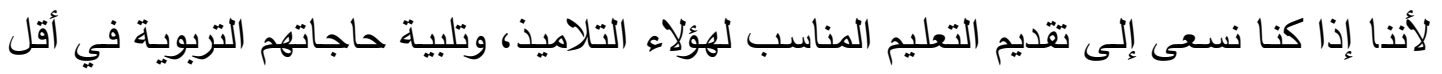

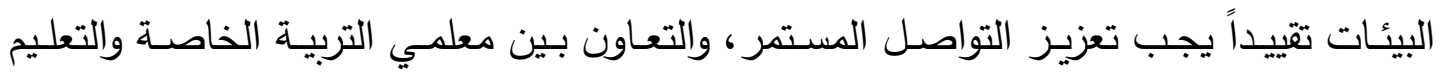

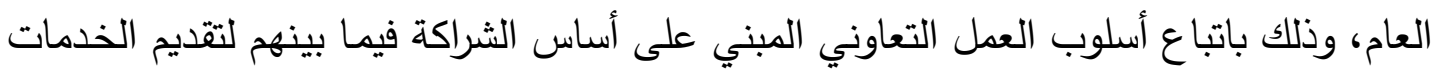

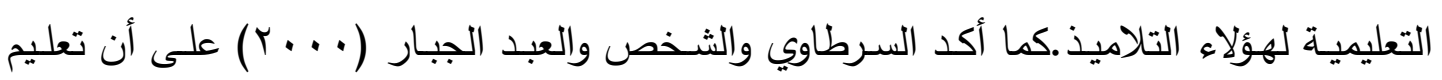

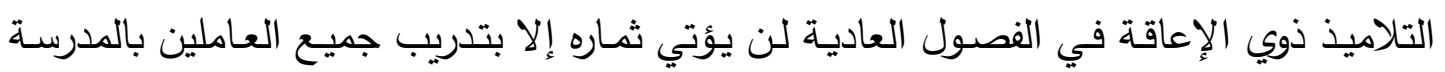
على المهارات التعاونية. وانطلاقاً من هذا الاهتمام بتوفير فريق متعاون تحت إطار أسلوب العمل التعاوني لتقديم

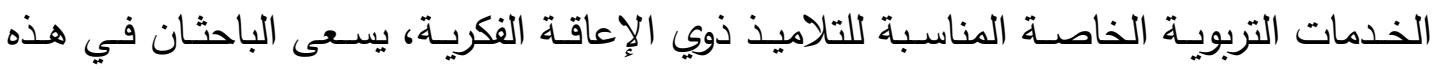

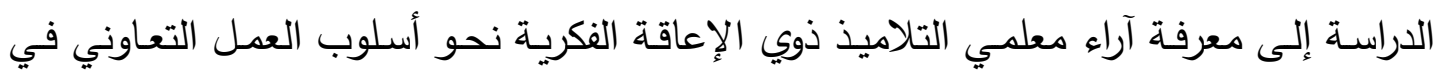
البيئة التعليمية لتلبية حاجات هؤلاء التلاميذ. 
إن تضـمين العمـل التعـاوني في العمليـة التعليميـة وكافـة الخـدمات التربويـة المقدمــة للتلاميذ ذوي الإعاقة الفكرية كأسلوب يقوم به العاملون في برامج دمج ذوي الإعاقة الفكريـة من معلمي التعليم العام والتربية الخاصـة يعتبر أمراً في غايـة الأهميـة، حيث أكدت دراسـة أبونيان

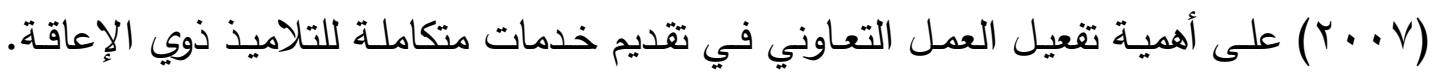
فهو يمثل أسلوباً فاعلاً في تضافر الجهود لتقديم جميع الخدمات التي يحتاجها هؤلاء التلاميذ، وبالتالي تحقيق أهداف مشتركة تصب في صالح هؤلاء التلاميذ. وقد سـاند تلك التوجهات مخرجات العديد مـن الدراسـات والأبحـاث التي أكدت على الحاجة لتفعيل أسلوب العمل التعاوني بين المعلمين في برامج التربيـة الخاصـة. ومـن الجدير بالذكر ما قامت به ألمانيا من تجارب ناجحة في تقديم خدمات التربية الخاصة والتدخل المبكر بشكل تعاوني، حيث يجتمع أعضاء الفريق المكون من تخصصات مختلفة لحل مشكلات تتعلق بالأطفال وأسرهم (التميمي، ب ( • r).مما سيجعل لجميع الأطراف المعنية بخدمة التلاميذ ذوي الإعاقة الفكرية أدواراً مهمة في تفعيل العمل التعاوني. في حين طالبت العديد من الدراسات بإعادة النظر في آلية تتفيذ أسلوب العمل التعاوني بين معلمي التعليم العام والتربية الخاصة، وتحديد أدوار كل منهما من حيث المشاركة في عملية التدريس، وتبـادل المعلومـات فيما بينهج وبين جميع العاملين في البرنـامج من اخصائيين؛ لمـا لذلك من تأثير على استفادة التلاميذ ذوي الإعاقة من الناحيـة التعليمية، كدراسـة فريند وكوك وهيرلي(Friend,Cook\&Hurley,2010) • ولمطابقـة هذه الرؤيـة للواقع الحالي في المملكة فإن هذه الدراسـة تعـد بمثابـة محاولـة علميـة للتعرف على آراء معلمي التلاميذ ذوي الإعاقـة والمسـاهمة في إيضـاح مفهوم ذلك الأسـلوب للمعلمين بدقـة، والتعرف على الأساسيات التي تؤهلهم للعمل كفريق تحت مظلة ذلك الأسلوب , وعليه تتبلور مشكلة البحث في محاولة الإجابة على الأسئلة الآتية: - مل 1- ما آراء معلمي ومعلمات التلاميذ ذوي الإعاقة الفكرية نحو أسلوب العمل التعاوني في البيئة التعليمية وعلاقته ببعض المتغيرات ؟ 


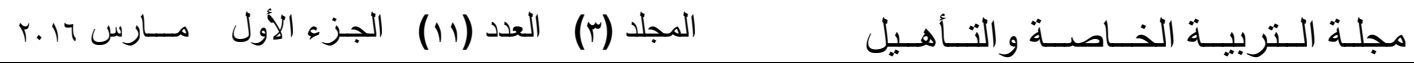

ץ- هل هناك فروق ذات دلالة إحصائية عند مستوى دلالة (0.05) في آراء معلمي ومعلمات التلاميذ ذوي الإعاقـة الفكريـة نحو أسلوب العمل التعـاوني في البيئة التعليميـة بنـاء على

$$
\text { متغير البيئة التعليمية (معاهد - برامج دمج) ؟ }
$$

ب- هل هناك فروق ذات دلالـة إحصائية عند مستوى دلالـة (0.05) في آراء معلمي التلاميذ ذوي الإعاقـة الفكربـة نحـو أسـلوب العمل التعــاوني في البيئـة التعليميـة بنـاء على متغيـر

$$
\text { الجنس (ذكور - إناث) ؟ }
$$

ع - هل هناك فروق ذات دلالة إحصـائية عند مستوى دلالة (0.05) في آراء معلمي التلاميذ ذوي الإعاقة الفكرية نحو أسلوب العمل التعاوني في البيئة التعليمية بناء على متغير سنوات الخبرة ؟

0- هل هنالك فروق ذات دلالـة إحصـائية عند مستوى دلالـة (0., • ) في آراء معلمي التلاميذ ذوي الإعاقة الفكرية ومعلمي التعليم العام نحو أسلوب العمل التعاوني في البيئة التعليمية ؟

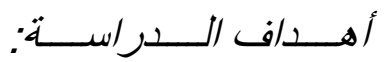

تهـدف الدراسـة الحاليـة إلىى: التعرف على آراء معلمي ومعلمـات التلاميذ ذوي الإعاقـة الفكريـة نحـو أسـلوب العمـل التعـاوني في البيئـة التعليميـة وعلاقتـهـ بـبعض المتغيـرات (البيئة التعليمية, الجنس, سنوات الخبرة, التخصص).

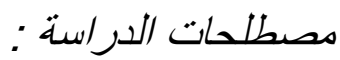

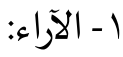

تعرف الآراء بأنها الدرجـة التي يحصل عليها أفراد الدراسـة بموجب المقياس الذي صمم

$$
\text { لغرض معين (الزبون و دورسوه، با ( ب). }
$$

وإجرائيـاً :هي انطباعات معلمي التربية الفكريـة ومعلمي التعليم العام نحو تفعيل أسلوب العمل التعاوني فيما بينهم في معاهد وفصول ذوي الإعاقة الفكرية الملحقة بالمدارس العادية. 
r - ب - معلمو التلاميذ ذوي الإعاقة الفكرياة:

تعـرف القواعد التتظيميـة معلمـي التلاميذ ذوي الإعاقـة الفكريـة بـأنهم الأشـاص الـذين يعملون على تعليم، ورعايـة، وتأهيل التلاميذ ذوي الإعاقـة الفكريـة في معاهد وفصـول التربيـة الفكرية الملحقة بالمدارس العادية (الأمانة العامة للتربية الخاصة، بrك اهـ). وإجرائياً :هم الأشخاص الذين يعملون مـع التلاميذ ذوي الإعاقة الفكريـة، ويقومون بتقديم الخدمات التربوية المناسبة لهم.

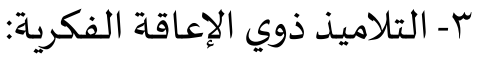
تعرف الجمعية الأمريكية للإعاقات الفكرية والنمائية (AAIDD) لعام ( • ( ب) التلاميذ ذوي الإعاقة الفكرية بأنهم أفراد يوجد لديهم انخفاض ملحوظ في الأداء العقلي والسلوك التكيفي الذي يغطي مجموعة واسعة من المهارات الاجتماعية اليومية والوظيفيـة، ويظهر ذلك قبل سن American Association on Intellectual and Developmental ) عاماً (Disabilities, 2010 وإجرائيـاً : هـ الأفراد الذين تم قبولهم بمعاهد التربيـة الفكريـة، وفصـول الإعاقـة الفكريـة الملحقة بالمدارس العادية التابعة لإدارة التربية والتعليم حسب الشروط المحددة من وزارة التعليم.

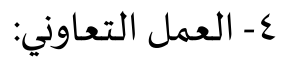

عـرف جريقـوري (Gregory, 2009)، العمـل التعـاوني بأنـه: "تعـاون فريـق العمـل لتطبيقإستراتيجية تعليمية فعالة في تعليم ذوي الإعاقة، والتي تتطلب تفاعل أعضاء الفريق فيما بينهم لوضع الأساس لعلاقات عمل ذات هدف مشترك" (p.26). وإجرائياً: الجهود المبذولة من قبل معلمي التربية الخاصـة والتعليم العام، والتي تهدف إلى التكاتف فيما بينهم لمواجهة حاجات التلاميذ، وحل مشكلاتهم التربوية. هـ البيئة التعليمية: تعرف البيئة التعليميـة بأنها "مجموعـة عوامل تؤثر في التعليم، وتسهم في تحقيق منـاخ جيد للتعلم يحصل فيه التفاعل المثمر بين كل من المعلم والمتعلم والمادة الدراسية، وتثمل كل 
من المرافق والتجهيزات والكتب الدراسية، وأسـاليب التدريس المختلفة، وإدارة الصف، والتفاعل

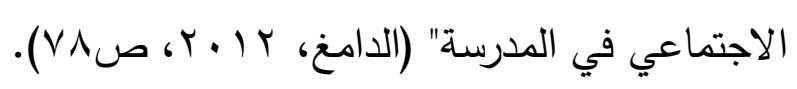
وإجرائياً: هي المكان الذي يحصل فيه تعليم وتدريب التلاميذ ذوي الإعاقة الفكريـة، وتقديم الخدمات والبرامج كافة لهم، سواء تلك المتصلة بالجانب التعليمي، أو النفسي، أو الاجتماعي. الإطار النظري و الدر/سات السابقة :

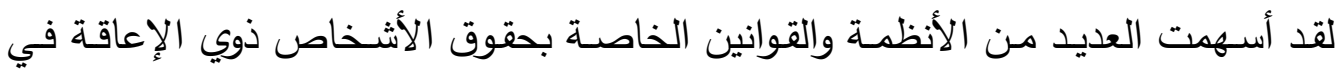
التغيير من طبيعة الخدمات المقدمة لهم. ففي عام (1975) تم إقرار القانون العام، وهو قانون Education of All التربية لجميع الأطفال ذوي الإعاقة في الولايات المتحدة الأمريكية Children Act , 1975)H\&icapped الإعاقـة على تعليم مناسـب ومجـاني، ثم تـوالى إصـدار قوانين إضـافية تتضــن المطالبـات المتزايدة بدمج الطلاب ذوي الإعاقات دمجاً شاملاً في بيئة التربية العادية (السرطاوي وآخرون، 2000). في حين أن "قانون تعليم الأطفال من ذوي الإعاقة لعام (2004) ( Individuals) (with Disabilities Improvement Act , 2004 - يطالب الحكومات المحلية في الولايات المتحدة وإدارات التعليم بها لتعزيز التعاون بين معلمي التعليم العام والتربية الخاصة" (IDEIA, 2004, p. 132). وبحسب ماأشار إليه ليرنر(Lerner, 1997) إن إقامة العلاقات الإنسانية بين المهنيين

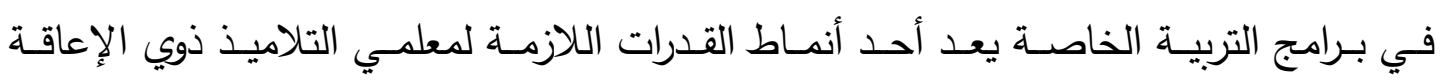
(في أبو قلة، V . . r), فإن تعليم التلاميذ ذوي الإعاقـة الفكريـة يتطلب تقديم خدمات متكاملـة وشاملة من أفراد ذوي تخصصـات متعددة يقوم على مبدأ التسيق والتواصل فيما بينهم ضماناً لإنجاح العملية التعليمية التربوية. ولا يخفى أن أسـلوب العمـل التعـاوني أصـبح أحد الخيـارات المهـــة التي تتيح الفرصــة للتفاعل بين المعلمين؛ وذلك لإشباع حاجات جميع التلاميذ في معاهد وبرامج التربية الفكريـة؛

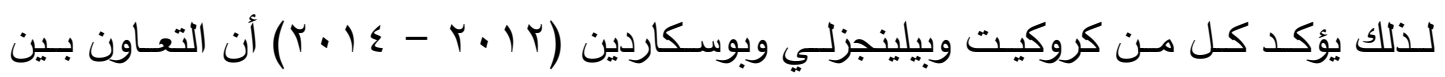


المعلمين سمة أساسية للتدريس والتعليم في هذا العصر ؛ لمواجهة التحديات التربويـة وتحسين قدرات التلاميذ ذوي الإعاقة الفكريـة.

إن مصطلح العمل التعاوني مصطلح عام يشير إلى عدد من المهنيين العاملين كفريق واحد في مجال التدريس، واتخـاذ القرارات المتعلقـة بالتلاميذ ذوي الإعاقـة الفكريـة. فقد عرف هيرناندز (Hernandez , 2013,p.4) العمل التعاوني بأنه: عبارة عن "الجهد المشترك من الأفراد ذوي الخبرات المتتوعة لتخطيط، وتنفيذ، وتقييم البرنامج التعليمي للطلاب". ومن هذا المنظور فإن العمل التعاوني عبارة عن عملية يشترك فيها اثنان أو أكثر من الأفراد المتخصصـين مـن أجـل تبـادل الخبـرات، وإيجـاد طـرق مبتكـرة للتفكيـر المشـرك لحل المشكلات التعليمية التي يشترك في تحديها هؤلاء الأفراد (Overall, 2005). ويُعد موضوع العمل التعاوني في برامج التربية الخاصـة وسيلة فاعلة لدعم تعلم التلاميذ ذوي الاحتياجـات التربويـة الخاصـة، حيث ارتبط التعـاون بين التربـويين ارتباطـاً وثيقاً بالنجاح الأكاديمي والاجتمـاعي للطـلاب ذوي الإعاقـة، وتحديداً في الفصـول الدراسية المدمجـة بالتعليم العـام(McLaren,Bausch\&Ault,2007). ولهـذا فـإن التأثير المحتمـل لأسـلوب العهـل التعاوني على أداء التلاميذ ذوي الاحتياجـات التربويـة الخاصـة سـيكون كبيراً. مدـا يؤدي إلى تحسين مستوى المهارات الأكاديمية والاجتماعية لهؤلاء التلاميذ، ورفع أدائهم الدراسي، وبخاصـة ذوي الإعاقة الفكرية (Garderen, Stormont \& Goel, 2012). وقد أشارت دراسات عديدة إلى فوائد مختلفة لأسلوب العمل التعاوني يمكن إيجازها على

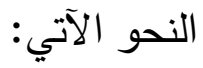
ا- العملية التعاونية بين المعلمين تساعد في تطوير المناهج، وابتكار أساليب تدريس تتوافق مع حاجات التلاميذ ذوي الإعاقات (Winn \& Blanton, 2005). ب- يتيح الفرصة لاكتساب المعرفة التي تمكن المعلمين من تحسين مهاراتهم التدريسية، والسعي نحو التطوير المهني (Smith \& Leonard, 2005). 
r- العمل التعاوني بين المعلمين يزيد من إحساسهم بالثقة، والتجديد، والإبداع والعلاقة التثاركية

.(Damore \& Murray, 2009)

ع - يسـاهم في تمكين معلم التربيـة الخاصــة والمعلم العـادي مـن تبـادل الأفكار ، والتخطيط

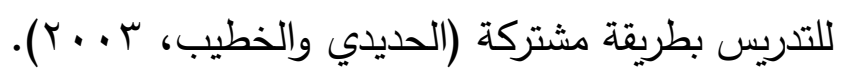

ه- إن أسلوب الععل التعاوني يساعد في تلبية الحاجات غير المتجانسـة لجميع التلاميذ ذوي

الإعاقة (Wiggins \& Damore , 2006).

צ- يعزز من مسؤولية معلمي التعليم العام والتربية الخاصـة اتجاه تحديد المشكلات الصفية لـدى التلاميـذ ذوي الإعاقـة في فصـول الــمج، وإيجـاد التـدخل لحلهـا بنجـاح وفاعليـة .(Rao, Hawkins \& Tan , 2011)

وعلى العكس فإن انعدام التعاون بين المتخصصين في تعليم التلاميذ ذوي الإعاقات

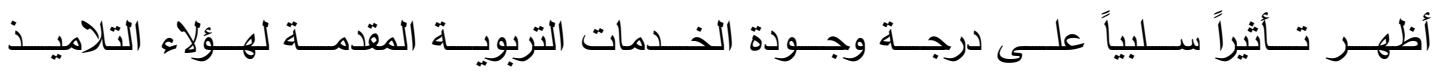
(Wallace,erson \&Bartolomay , 2002)

قد تكون العلاقات بين المعلمين في أولى مراحل العمل التعاوني سطحية؛ مما يشعر البعض منهم بوجود حواجز تحد من تكوين علاقة مهنية مع زملائهم (الحديدي، والخطيب،

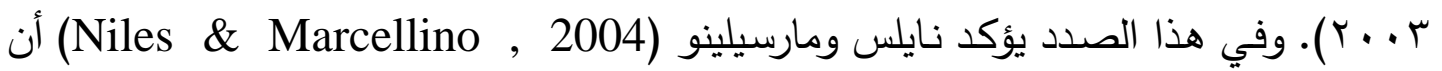
نجاح العمل التعاوني بين المعلمين يكون مبنياً على العلاقة الثخصية التي يتم تطويرها بين

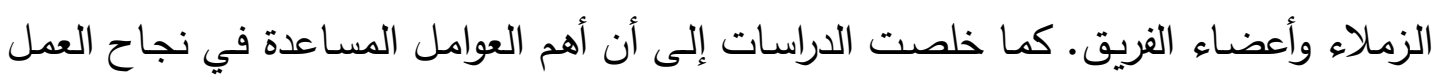
التعاوني بين المعلمين كانت على النحو التالي: اتجاهات المعلمين، والدعم الإداري، ومهارات الاتصـال، وتوفير الوقت، ومهـارة إدارة الصـف، وتبـادل الخبرات والتتعلم فيمـا بيـهم، وتقاســـ Brinkmann \& Twiford , 2012 McClure , ) المسؤوليات، والثقة المتبادلة بين الطرفين Patton\&1995;

من أهم عناصر إنجاح العمل التعاوني (Wiggins \& Damore , 2006). 
ويؤكد كل من بلانتون وبقشش (Blanton \& Pugach, 2007) أن المطالبات القانونية بتوفير الخدمات التربوية لجميع التلاميذ ذوي الإعاقة في أقل البيئات تقييداً، أوجدت واقعاً يفرض إعادة النظر في العلاقة بين معلم التعليم العام والتربيـة الخاصـة، وإعداد كـلا الطرفين للعمل التعاوني, ومن هنايرى الباحثان ضرورة إيجاد شراكة تعاونية بين المعلمين.ووفقاً لكل من هولدهايد وريسجلي (Holdheide \& Reschly, 2008) تبرز أهمية إعداد معلمي التربية الخاصـة والتعليم العام للعمل التعاوني؛ لتصبح أدوارهم أكثر فاعلية من خلال إكسابهم المهارات التعاونية والتدريب عليها، وذلك بالاستفادة من برامج التدريب وذوي الخبرات الميدانية, وبالرغم من تلك الأهمية لإعداد معلم التعليم العام والتربية الخاصة للعمل معاً وفق الأسلوب التعاوني يؤكد جريفين برديج وجونز وكلجوري (Griffin, Jones \& Kilgore, 2007) وجود ندرة في الدراسات التي تطرقت لإعداد هؤلاء المعلمين للتعاون في فصول الدمج الشامل.

ويشير كل من هولدهايد وريسجلي (Holdheide \& Reschly , 2008) إلى تسعة عناصر يجب تدريب معلمي التربية الخاصة والتعليم العام عليها، وتُعد تلك العناصر مؤشرات دالة على توافر الكفايات المهنية لاى هؤلاء المعلمين، وهي: التخطيط كفريق تعاوني، والتدرب على المهارات التعاونيـة، والقدرة على تطوير واستخدام الــنهج العـام وتكييفـه حسب حاجـة التلاميذ، وإستراتيجيات التعلم، وإدارة السلوك، والاتصـال والتشاور مع الآباء، والمعرفة بأساليب تقييم التلاميذ، والمعرفة بتشريعات وقوانين الدمج الثامل، والاشتراك مع فريق العمل بفاعلية.وقد أكد جونز وفيل (Jones \& Vail , 2014) على أهمية هذه الكفايات من خلال دراسة تضمنت سؤال المشـاركين فيها من معلمي التربية الخاصـة قبل الخدمة حول مـا يحتاجهه معلم التربيـة الخاصة للقيام بعمل تعاوني مع معلم التعليم العام بطريقة فاعلة، وكانت الكفايات التي ذكروها على النحو التالي: معلومات حول فكرة التعاون وما يرتبط بها من أبحاث، والتواصل الفعال للتعامل مـع الأسر والاختصاصيين، ومعلومات حول القيم والمعتقدات والممارسات الأخلاقيـة، ومهارات في تكوين الفريق، وتثمل التواصل من خلال التدريس والتخطيط والتقييم. حيث يرى

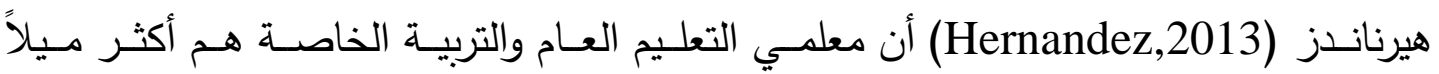




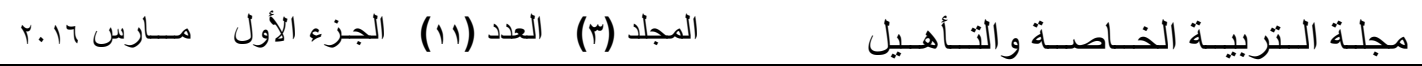

للانخراط في تكوين علاقات تعاونيـة إذا مـا تم تأهيلهم وإعدادهم من خـلال إكسـابهم مهارات العمل التعاوني، وتعريفه بمفاهيمه بما يتماشى مع أدوارهم وممارساتهم التدريسية. وتأسيساً على ذلك فإن الأدوار المنوطة بمعلم التعليم العام لا تقل أهمية عن دور معلم التربية الخاصة، حيث إن وجود التلاميذ ذوي الإعاقة في الفصول الدراسية العادية أصبح تحدياً يتطلب مـن الجميـع التكـاتف والعمل بطريقـة تعاونيـة لإتاحـة الفرصـة لجميع المعلمين لتبـادل الأفكـار والخبـرات والمعـارف المتعلقـة بتعلـيم هـؤلاء التلاميـذ، ومعرفـة خصائصـهم وأسـاليب تدريسهم، ممـا يحتم على المعلمين المنـاداة بضـرورة التطوير المهني لمعلمي التربيـة الخاصـة والتعليم العـام؛ لتفعيل العمل التعـاوني على نحو يسـهم في إيجـاد بيئـة تربويـة ملائكـة لجميع التلاميذ ذوي الإعاقـة في المدارس العاديـة. ومـا لمسـه الباحثان من بعض الدراسـات _ كدراسـة ليدوكس وجرافز وبيورت (LeDoux ，Graves \&Burt , 2012) أن من التحديات التي تواجه معلمي التعليم العام في فصول الدمج الثـامل عدم إعطاء أسلوب العمل التعاوني القدر الكافي مـن الاهتمـام، ومطالبـاتهم بمشـاركة معلمي التربيـة الخاصـة في تـدريس التلاميذ ذوي الإعاقة، ووضع الأهداف العامة المشتركة، واتخاذ القرارات_فإنه يقتضي إيضـاح النماذج والأطر العامـة لأسـلوب العمـل التعـاوني لضـمان حصـول هـؤلاء التلاميذ على تعليم عـالي الجـودة، وخدمات تربوية داعمة تناسب حاجات كل تلميذ على حدة. Sharpe \& ( وفيما يتعلق بنماذج تقديم الخدمات التعاونية يصف كل من شارب وهاوس (Hawes, 2003 خمس خطوات عمليـة تُعد كإستراتيجيه فعالـة لجلب معلمي التعليم العام والتربيـة الخاصـة للعمل معـاً لمواجهـة حاجـات التلاميذ الأكاديميـة والاجتماعيـة ضـمن أسلوب العمل التعاوني، حيث ترتكز هذه الخطوات على: ا- التواصل بين معلم التعليم العام والتربيـة الخاصـة لتحديد المعايير ومهمات الأداء ومتطلبات المناهج الدراسية التي سيتعرض لها التلاميذ ذوو الإعاقات. ץ- مناقشة الحاجات التعليمية، ومدى توافر الموارد اللازمة لتعليم التلاميذ. 
r- اتخـاذ القرارات المتعلقـة بإقامـة التلاميذ، والسـماح لهم بالمشـاركة في التعليم بقدر

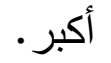

ع - تحديد المسؤول عن مراقبـة فعاليـة إقامـة التلاميذ ذوي الإعاقـة في فصـول التعليم العام. 0- تحديـد الأهـداف التربويـة للتلاميذ، ومناقثـة آليـة تقيـيمهم وفقـاً للأهـداف المحددة باستخدام المعايير الموضوعية.

كما يتضمن أسلوب العمل التعاوني العديد من النماذج التعاونية المتاحة للمعلمين، ومن تلك النماذج نموذج التدريس التعاوني (Co-teaching) والذي يُعد من النماذج المباشرة في تقديم الخدمات، وقد أصبح أحد أهم إستراتيجيات الدعم المستخدمة في فصول التعليم الثـامل لتقديم الخدمات (Gerry , 2013). ويُقصد بهذا النموذج تعاون معلمي التعليم العام والتربية الخاصـة بطريقة مباشرة في كل ما يتعلق بالعملية التعليمية من تحمل جميع المسؤوليات التعليمية لجميع التلاميذ في غرفة الصف، بحيث يعملان معاً لتكييف المنهج على نحو يلبي جميع حاجات التلاميذ غير المتجانسـة، ويتشاركان في وضع الأهداف للخطة التربويـة الفردية، ووضـع أهداف مشتركة تساعد على عملية التخطيط والتنفيذ والتعليم وإدارة الصف بهدف تحسين البيئة التعليمية لهؤلاء التلاميذ وتقديم خدمات أكثر شمولية (Gregory , 2009). في حين يُعد نمـوذج تدريب الزمـلاء (Peer Coaching) أحد النمـاذج غير المباشرة لتقديم الخدمات التعاونيـة، حيـث يعمل المعلمـون على إتقـان المهـارات الجديدة التي يتحقق اكتسابها من بعضهم بعضاً، سواء من خلال الملاحظة، أو الممارسات الفعلية للعمل التعاوني فيما بينهم، ولقد أوضـح كل من جوس وشاورز (Joyce \& Showers, 1980) S S.ن تدريب الزملاء يتضمن الخطوات التالية: 1- عرض نظري للمفاهيم حول أساليب وإستراتيجيات معينة من التدري. ץ- النمذجة، بحيث يقوم المدرب (Coach) بممارسـة المهارات الجديدة في غرفة الصف؛ ليسهل انتقالها للمعلم المتدرب. 


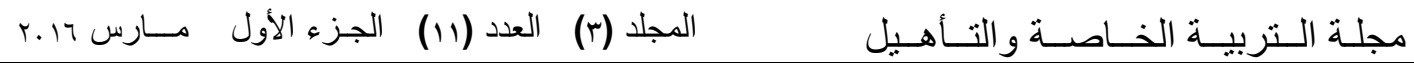

ب- الممارسة الفعلية، وتتضمن قيام المعلم المتدرب بإجراء عدة تطبيقات للمهارات والأساليب

التي تمت ملاحظتها، مع توافر الدعم من زميله المدرب.

ع - تغذية راجعة منتظمة يقدمها المدرب لكل تطبيق يقوم به المعلم المتدرب.

0- تغذية راجعة متبادلة بين كلا المعلمين بعد عملية التطبيق.

كما يُعد نموذج فريق التعليم (Team Teaching) أحد نماذج تقديم الخدمات التعاونية، ويعرف مكليرن وآخرون (McLaren, et al,.2007) فريق التعليم التعاوني بأنه مجموعة من المعلمين تعمل معاً، وتتشارك في الأهداف وفي المهام والمسؤوليات، كما تقوم بالتدريس والتقييم للمجموعة نفسها من التلاميذ بصورة منتظمة. ويؤكد هذا النموذج على اشتراك كل من معلمي التربية الخاصـة والتعليم العام بصورة مباشرة في كل ما يتعلق بالعملية التعليمية داخل الصف، ويتميـز نمـوذج فريـق التعليم بتقاسـم المسؤوليات بـين معلمـي التربيـة الخاصـة والتعليم العـام بالتسـاوي فيما يتعلق بتخطيط وتنفيذ البرامج التعليمية (Cramer , 2006). وفي هذا النموذج لا تقتصـر أدوار كل مـن معلمي التربية الخاصـة والتعليم العـام على تحمل مسؤولية المحتوى الأكـاديمي فقط، ولكنهـا تمتـد لتشـمل جميع التلاميذ في الصـف مـن ذوي الإعاقـة وغيـر ذوي الإعاقة، ويسهم فريق التعليم في توفير الفرص للتلاميذ للوصول بهم إلى أقصى حد تسمح بـه قدراتهم فضلاً عن أنه يعمل على صقل خبرات المعلمين أنفسهح (السرطاوي وآخرون، ب . . ؟). وعلى الرغم من تزايـد الاهتمـام بالممارسـات التعاونيـة بين معلمي التعليم العـام والتربيـة الخاصـة فإن مستوى ممارسـة العمل التعاوني بين المعلمين كأسـلوب لتقديم الخدمات التربويـة للتلاميذ ذوي الإعاقة لا يزال ضعيفاً، كونه يتأثر ببعض التحديات التي قد تضعف مستوى تلك الممارسات التعاونية. ويشير رايس (Reyes , 2010) إلى أبرز الصعوبات التي تحد من تفعيل العمل التعاوني بين معلمي التربيـة الخاصـة والتعليم العام، وهي: عدم توافر الدعم الكافي من إدارة المدرسـة للعمـل التعـاوني بـين المعلمين، وقلـة الوقت المخصـص لتتفيذ وتخطيط العمل التعـاوني ومتابعـة الأداء الحـالي للتلاميذ، وعدم استعداد معلمي التعليم العـام لتعديل المنـاهج الدراسية بمـا يتناسـب مـع حاجـات التلاميذ ذوي الإعاقـة، وضـفف الكفايـات المهنيـة للمعلمين، 
وتوجهات المعلمين السلبية نحو العمل التعاوني. وفي هذا الشـأن يُعد افتقار المعلمين للدعم الإداري أحد الصعوبات التي تحد من ممارسة أسلوب العمل التعاوني فيما بينهم، حيث إن عدم إدراك بعض الإدارات المدرسـية لأدوار معلمي التربيـة الخاصـة ومعلمسي التعليم العـام، وعدم إعطائهم الوقت الكافي لممارسـة أدوارهم التعاونية بطريقة فعالة يجعل من عمل المعلمين أكثر صعوبة (Worrell , 2008) • ولقد توصلت العديد من الدراسـات إلى أن ضعف دعم إدارة المدرسة، وعدم إيجاد بيئة داعمة للعمل التعاوني بين المهنيين فيما بينهم يُعد من أبرز التحديات Hines, 2008; Wiggins \& Damore ) التي تحد من مستوى ممارسة العمل التعاوني فيها 2006 ,) في حين يؤكد سـانتانجيلو (Santangelo ， 2009) على أهميـة دعم الإدارة المدرسية للمعلمين لتنفيذ نماذج العمل التعاوني فيما بينهم، حيث يُعد الدعم الإداري من أهم العوامل لإيجاد تعاون فعال بين المعلمين في المدرسة. ومن جهة أخرى تُعد قلة الوقت المخصص للتخطيط عائقاً أكبر لممارسة العمل التعاوني بين المعلمين (Wouk, 2007) ; Binn \& Blanton, 2005 ). حيث يقترح كل من براونل وآخرون (Brownell , et al. , 2006) لتكوين تعاون فعال بين المعلمين ضرورة إيجاد الوقت الكافي للتخطيط المشترك، والعمل معاً لدعم العملية التعليمية للتلاميذ ذوي الإعاقة، ومتابعة ما يتعلق بأدائهم الدراسي. كمـا تُعد العزلة بين المعلمين من الصـوبات الشـائعة في المدارس، والتي تعيق عمليـة التعاون بين بعضهم بعضاً (Cookson , 2005). حيث يشير تانوك (Tannock , 2009) إلى أن القضاء على العزلة بين المعلمين في مدارس الدمج الثامل يتطلب التعاون بين معلمي التربية الخاصـة والتعليم العام في اتخاذ القرارات الداعمة لتعليم التلاميذ ذوي الإعاقات في تلك المـدارس, ومـن تلك الصـوبات أيضـاً ضـعف الكفايات المهنيـة للمعلمين، بحيث يـرى معلمو التعليم العام أنهم بحاجة إلى التدريب على المعارف والمهارات اللازمة لتقديم الخدمات التربويـة للتلاميذ ذوي الإعاقة في فصول التعليم العام (Brownell et al, 2006). 


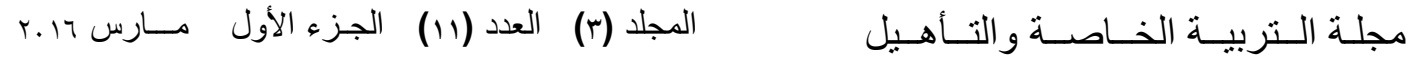

وتأسيسـاً على مـا تم التطرق إليـه فـإن الحاجـات التربويـة للتلاميذ ذوي الإعاقات الفكريـة

أكثر تعقيداً منها لدى التلاميذ من غير ذوي الإعاقة، مما يفرض ذلك تقديم الخدمات التربويـة للتلاميذ ذوي الإعاقات ضمن فريق تعليمي يتمتع بروح العمل التعاوني، بحيث يؤدي عمله على أساس من التستيق والتكامل، وتبادل الخبرات والمعلومات، سواء في مراحل تشخيص الحالات،

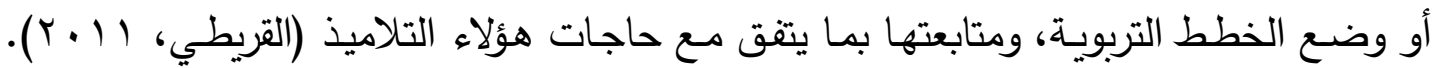
ومن الضروري الفهم الواضح للعمل التعاوني، وعناصره الأساسية، ونماذجه المتعددة، حيث يُعد ذلك شرطاً أساسياً للبدء بالجهود التعاونية المشتركة بين المعلمين في تقديم الخدمات للتلاميذ ذوي الإعاقة، وهذا ما تسعى إليه دراستتا الحالية من خلال الكثف عن أسلوب العمل التعاوني بين المعلمين في البيئة التعليمية.

$$
\begin{aligned}
& \text { الطـــبةتهـة والإجــراء/ت: } \\
& \text { منهــج الـدراسـة: }
\end{aligned}
$$

اتبع الباحثان المنهج الوصفي خـلال جمع المعلومـات عن مشكلة الدراسـة، والذي يهتم

بدراسة الظاهرة في الواقع ووصفها وصفاً دقيقاً.

$$
\text { عينــة الــدراسـة: }
$$

تكونت عينـة الدراسـة النهائية من (Y Y ( ) من معلمي التلاميذ ذوي الإعاقـة الفكريـة في معاهد

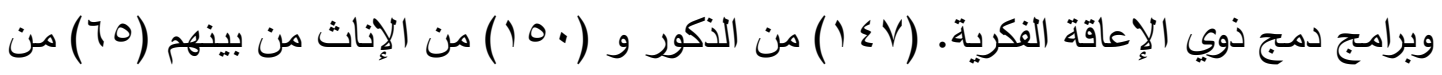
معلمي التعليم العام الذين يقومون بتدريس التلاميذ ذوي الإعاقة الفكرية

اسـتخدم الباحثان - اسـتبانة آراء معلمي التلاميذ ذوي الإعاقـة الفكربـة نحو أسـلوب العمل التعاوني في البيئة التعليمية - كأداة لجمع البيانات من العينة، حيث تم بناء فقراتها من خلال الاستفادة من الأدبيات والدراسات السابقة ذات العلاقة بموضوع الدراسـة الحالية، واشتملت الأداة على متغيـرات تتعلق بمعلىي التلاميذذ ذوي الإعاقـة الفكريـة في معاهد وبـرامج الـمـج الملحقة بمدارس التعليم العام من حيث (البيئة التعليميـة، سنوات الخبرة، الجنس، التخصص)، 
كما تكونت الأداة من أربعـة أبعاد تتضـن (ب^) عبارة تعكس الأبعاد الرئيسـة للدراسـة، موزعـة على النحو التالي: - ملي:

البعـد الأول: ويتكـون مـن (9) عبارات تشمل التعرف على آراءمعلمي التلاميذ ذوي الإعاقـة الفكريـة نحو أسلوب العمل التعاوني كأحد الأسـاليب الحديثة في تقديم الخدمات التربويـة

للتلاميذ ذوي الإعاقة الفكرية في معاهد وبرامج دمج ذوي الإعاقة الفكرية.

البعد الثاني: ويتكون من (• (1) عبارات تشمل التعرف على مدى إلمام معلمي التلاميذ ذوي الإعاقة الفكرية بالعناصر الأساسية اللازمة لإنجاح العمل التعاوني فيما بينهم.

البعـد الثالث: ويتكـون مـن (9) عبارات تشمل الكفايات الأساسية لدى معلىي التلاميذ ذوي الإعاقة الفكرية التي تؤهلهم للعمل التعاوني.

البعد الرابـع: ويتكون من ( • 1) عبارات تشمل المعوقات التي تحد من تطبيق أسلوب العمل التعاوني في معاهد وبرامج الدمج من وجهة نظر معلمي التلاميذ ذوي الإعاقة الفكرية. صــــدق الأداة: أ) الصدق الظاهري لأداة الدراسة: للتحقق مـن الصـدق الظـاهري (صـدق المحكمـين) لأداة الدراسـة تـم عرضـها بصـورتها الأوليـة على (V) محكمين من أعضاء هيئة التدريس في قسم التربيـة الخاصـة، وأعضـاء هيئة التدريس في قسم علم النفس بجامعة الملك سعود وجامعة الإمام محمد بن سعود، وذلك للتعرف على آرائهح من حيث سلامة صياغة عبارات الأداة، ومدى وضوح العبارات، ومناسبتها لأهداف الدراسة، وإضافة أو حذف أو تعديل بعض العبارات. وبعـد أن كـان عـدد العبـارات في محساور أداة الدراسـة بصـورتها الأوليـة (• ع) عبـارة، أصبحت بعد التحكيم (^^) عبارة, بحيث تم الأخذ بالملاحظات الواردة على الإستبانة .

ب): Internal consistently Validity الصدق الداخلي (الاتساق الداخلي) لحساب صدق الاتساق الداخلي للاستبانة تم التطبيق على عينة استطلاعية مكونة من ( • ع ) فرداً من معلمي ومعلمات تلاميذ ذوي الإعاقة الفكريـة، كما قام الباحثان بحساب معامل 
ارتباط بيرسون بين الدرجة لكل عبارة والدرجة الكلية للمحور الذي تتنمي إليه، وأيضاً معامل الارتباط بين كل محور والدرجة الكلية للاستبانة.

$$
\text { ثبـــــات أداة الــــدر اســــة: }
$$

Cronbach's لقياس مدى ثبات أداة الدراسة، استخدم الباحثان معادلة(ألفا كرونباخ) Alpha يدل على ارتفاع درجة ثبات جميع محاور (الاستبانة) • نتائج الدراسة ومناقشتنها:

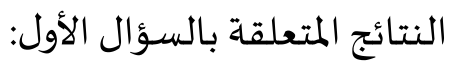
ما آراء معلمي ومعلمات التلاميذ ذوي الإعاقة الفكرية نحو أسلوب العمل التعاوني في البيئة التعليمية ؟ ولإجابة عن هذا التساؤل, تم حساب التكرارات، والنسب المئوية، والمتوسطات

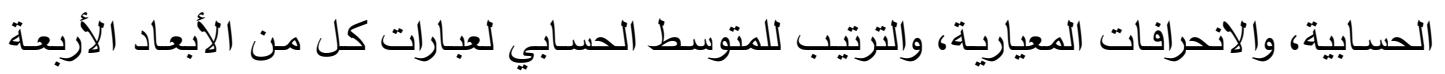
لأسلوب العمل التعاوني في البيئة التعليمية.

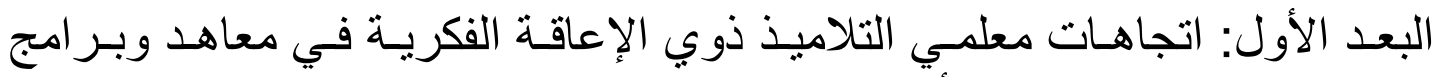
التربية الخاصة نحو أسلوب العمل التعاوني:

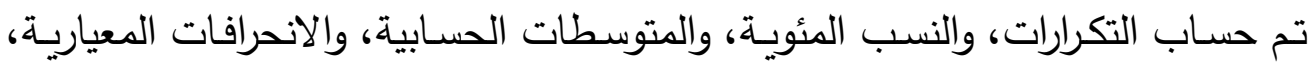

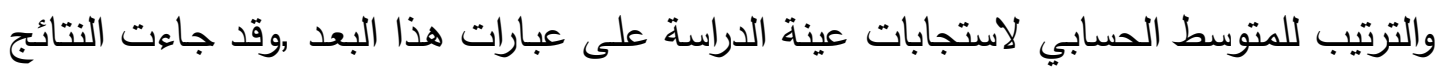
كما هي موضحة بالجدول ( (1) على النحو التالي : لابندابن

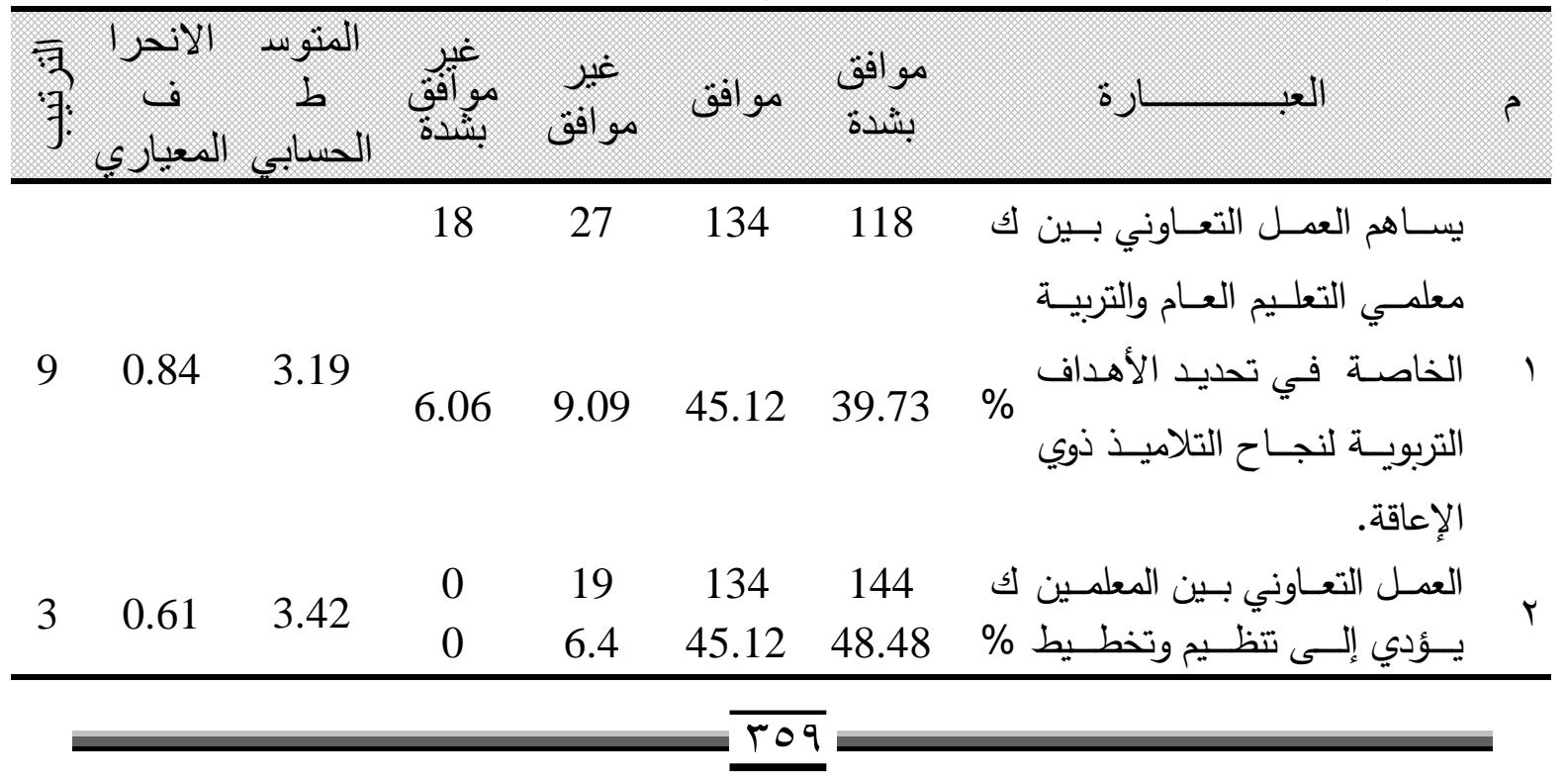




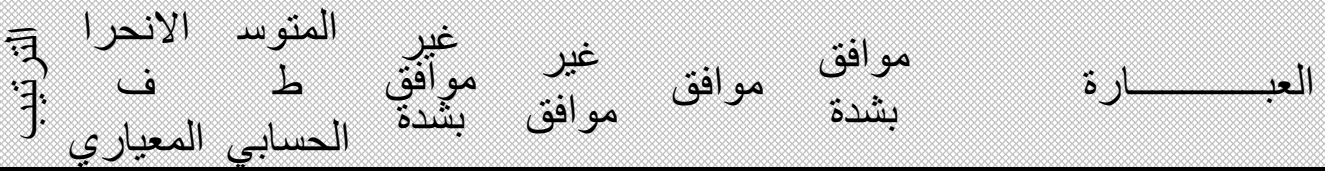

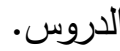

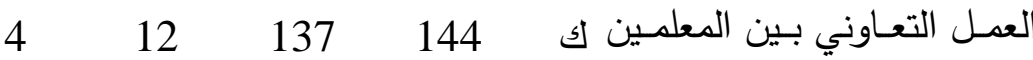

$3 \quad 0.64 \quad 3.42$

الفكريسة على اكتساب وتطوير \% $1.35 \quad 4.04 \quad 46.13 \quad 48.48$ إستراتيجيات تعلم فاعلة.

العمل التعاوني بين المعلمين يزيد كي $149 \quad 13512$

$2 \quad 0.59 \quad 3.45$

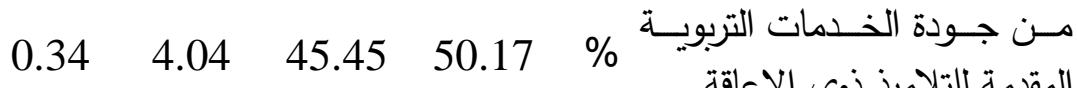
المقدمة للتلاميذ ذوي الإعاقة.

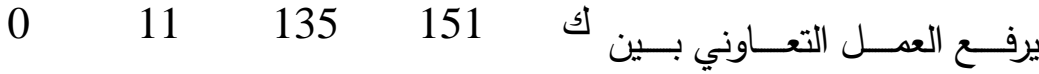

$\begin{array}{lll}1 & 0.57 & 3.47\end{array}$

0

يتطلـب العهـل التعـاوني بـين كئ $128 \quad 22 \quad 138 \quad 22$

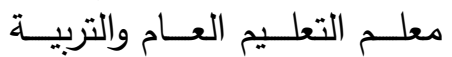

$\begin{array}{lll}7 & 0.74 & 3.3\end{array}$

الخاصة إلى توفير الوقت لهما للقيام بذلك.

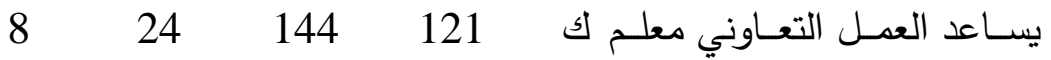

$\begin{array}{lll}8 & 0.72 & 3.27\end{array}$

لاكتساب وتطوير إستراتيجيات \% تدريس فاعلة.

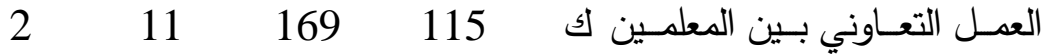

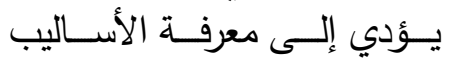

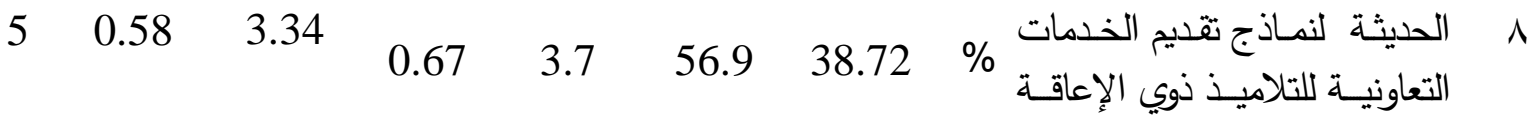
الفكرية.

ينبغـي لمعلمسي التعلـيم العـام كـ $125 \quad 17 \quad 150 \quad 5$ $\begin{array}{lll}6 & 0.66 & 3.33\end{array}$

$1.68 \quad 5.72 \quad 50.51$

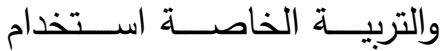
9 بطريقة تعاونية. $0.66 \quad 3.35$ المتوبط العام للبُعد

يتضـح مـن الجـدول (1) آراء أفراد عينـة الدراسـة مـن معلمي ومعلمـات التلاميذ ذوي 


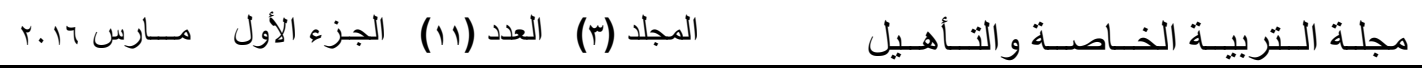

الإعاقـة الفكريـة حول درجـة موافقتهم على عبارات البعد الأول: اتجاهـات معلمي التلاميذ ذوي الإعاقـة الفكريـة في معاهــــــرامج التربيـة الخاصـة نحـو أسـلوب العمـل التعـاوني، فقد كـان المتوسط الحسابي العام لهذا البُعد (0ب,r)همما يعني أن معظم أفراد العينة من معلمي ومعلمات تلاميذ ذوي الإعاقة الفكرية يوافقون بدرجة (موافق بشدة) على عبارات هذا البعد بوجه عام. حيث جاءت عبارة (يرفع العمل التعاوني بين المعلمين من إنجازهم وتقاعلهم مـع التلاميذ ذوي الإعاقة الفكريـة) في المرتبـة الأولى، بمتوسط حسابي (V) (Y). ويستشف من هذه النتائج أن العمل التعـاوني بين معلمي التعليم العـام ومعلمي التلاميذ ذوي الإعاقـة الفكريـة يرفـع مـن إنجازهم وتقاعلهم مـع هؤلاء التلاميذ، حيث تتصدر هذه العبارة اتجاهات المعلمين نحو العمل التعاوني، وقد تكون هذه النتيجة متوقعـة إذا أخذنا في الاعتبـار تحديد الأدوار وتقاسـها بين معلمي التعليم العام والتربية الفكريـة عند التزامهم بتقديم الخدمات للتلاميذ ذوي الإعاقة الفكريـة بأسلوب تعاوني، مما سيسهم في تطوير ممارسات هؤلاء المعلمين، ورفع إنجازهم وتفاعلهم مـع تلاميذهم بقدر أكبر موتتفق هذه النتيجـة في الدراسـة الحاليـة مـع دراسـة والـدرون وماكليسكي (Waldron\&2010Mcleskey,) والتي ذكر فيها الباحثان أن الشراكة التكاملية بين معلمي التعليم العـام والتربيـة الخاصـة أدت إلى التطـور في الممارسـات التدريسية لهـؤلاء المعلمين وإنجازهم، وارتفاع تفاعلهم مع التلاميذ ذوي الإعاقة الفكرية. وفيما يتعلق بالعبارات التي تذيلت القائمة تأتي عبارة (يساهم العمل التعاوني بين معلمي التعليم العـام والتربيـة الخاصـة في تحديد الأهداف المشتركة لنجاح التلاميذ ذوي الإعاقـة) في المرتبـة التاسـعة والأخيـرة، وبمتوسـط حسـي (9 (ـ)، وعلى الـرغم مـن أن هذا المتوســ لا يخرجها من درجة -موافق - إلا أنها محل خـلاف بين أفراد العينة، ويمكن تفسير هذه النتيجة بأن هناك بعضاً من معلمي التعليم العام والتربية الفكرية لا يؤيدون العمل التعاوني فيما بينهم، بينما يفضلون العمل الفردي المستقل عند تحديد الأهداف التربويـة للتلاميذ ذوي الإعاقة، ولعل ما جاء في دراسـة كارتر وآخرون (Carter, et al, 2009)يجعل من تفسير هذه النتيجة في الدراسـة الحالية تفسيراً منطقياً، حيث وضع الباحثون نموذجاً تعاونياً للتعرف على كيفية تطبيقه 
من قبل معلمي التربيـة الخاصـة ومعلمي التعليم العـام، ومـن ضـمن خطواتـه تحديد الأهداف المشـتركة للتلاميذ ذوي الإعاقـة بصـورة مشـتركة بين المعلمين، وعند استعراض آراء المعلمين وتجربتهم في تطبيق ذلك النموذج جاءت نتائج الدراسـة متوافقة مع النتيجة السابقة، بحيث قام بعض المعلمين بتطبيق خطوات النموذج التعاوني بطريقة منفصلة عن زملائهم الآخرين، مدا يؤكد على عدم تأييدهم للعمل التعاوني.

البعد الثاني: العناصر الأساسية اللازمة لإنجاح العمل التعاوني بين المعلمين.

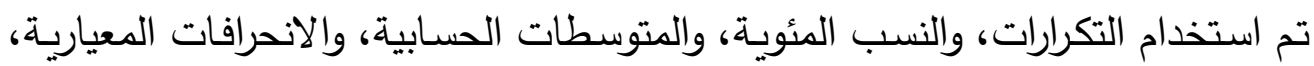
والترتيب للمتوسط الحسـابي للتعرف على آراء عينـة الدراسـة نحو هذا البعد.وقد جاءت النتائج كما هي موضحة في الجدول رقم (Y) على النحو التالي:

\begin{tabular}{|c|c|c|c|c|c|c|c|c|}
\hline न. & 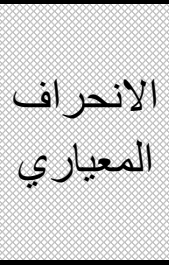 & |ll| & 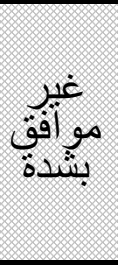 & كو افت & هو افت & كو افت & العبارة & r \\
\hline 2 & 0.65 & 3.49 & 2.02 & 2.69 & 39.06 & 56.23 & 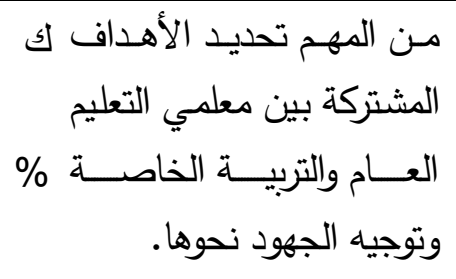 & 1 \\
\hline 4 & 0.64 & 3.41 & 1.35 & 4.04 & 46.8 & 47.81 & 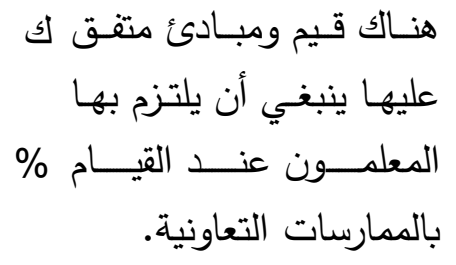 & r \\
\hline 3 & 0.68 & 3.46 & 1.68 & 5.72 & 37.71 & 54.88 & 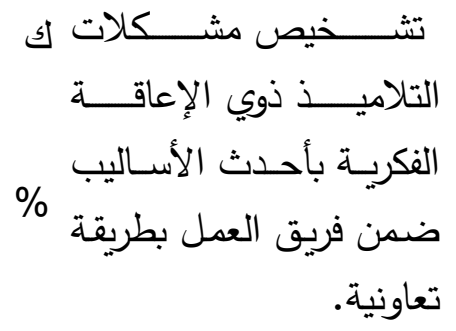 & r \\
\hline 1 & 0.54 & 3.62 & $\begin{array}{c}1 \\
0.34\end{array}$ & $\begin{array}{c}5 \\
1.68\end{array}$ & $\begin{array}{c}101 \\
34.01\end{array}$ & $\begin{array}{c}190 \\
63.97\end{array}$ & 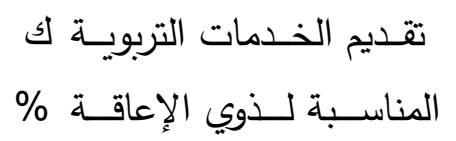 & \\
\hline
\end{tabular}


مجلة الـتربيـة الخـاصـة والتـأهيل المن

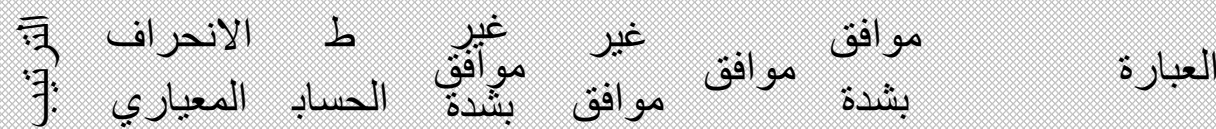
s

الفكريــة يتطلـب الاحتــرام

المتبادل بين معلمي التعليم

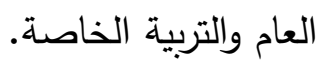

يحقق العمل التعاوني بين ك5 $13813 \quad 13 \quad 130$

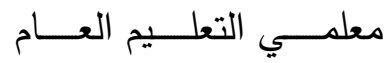

$\begin{array}{lll}5 & 0.67 \quad 3.38\end{array}$ $2.02 \quad 4.38 \quad 47.14 \quad 46.46 \quad \%$

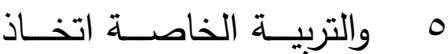

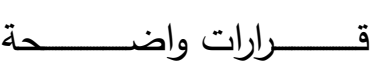

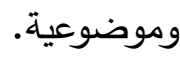

مسـن الضــروري تقاسـم ك5 813913317

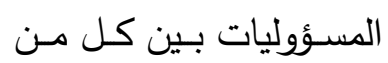

$\begin{array}{lll}6 & 0.71 \quad 3.36\end{array}$

$\begin{array}{lllll}2.69 & 5.72 & 44.78 & 46.8 \quad \%\end{array}$

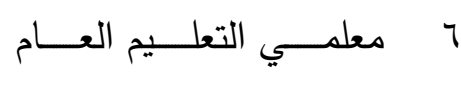
والتربيــة الخاصـــة فــي المدرسة.

يحقق العمل التعاوني بين ك5 $14 \quad 46 \quad 40$ معلدـي التعلــيم العـام التهام

$\begin{array}{lll}9 & 0.78 & 3.11\end{array}$

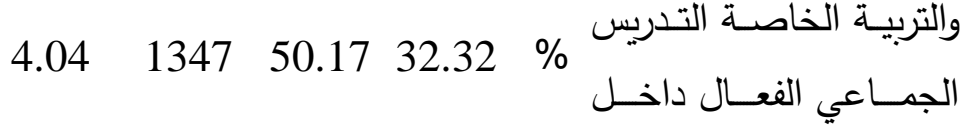
الفصل الدراسي العادي.

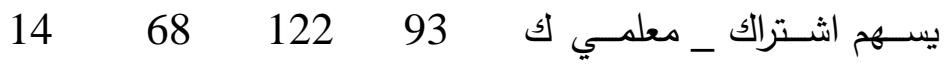
التعلـيم العــام والتربيـــة

$\begin{array}{lll}10 & 0.86 & 2.99\end{array}$ الخطـة التربويـة الملائعـة \%

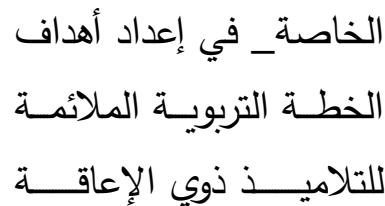
الفكرية. $\begin{array}{lllllllll}8 & 0.81 & 3.14 & 13 & 39 & 137 & 108 & 5\end{array}$ 
wis

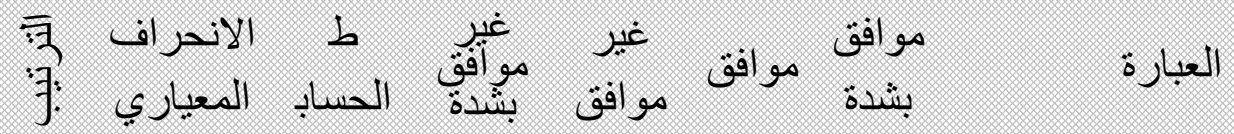
ي

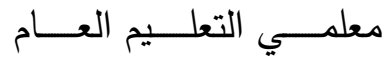

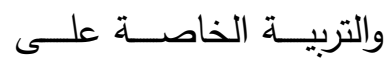

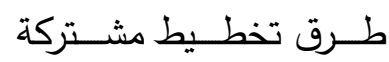

لإكساب المحتوى المناسب \% $436.38 \quad 13.13 \quad 46.13$

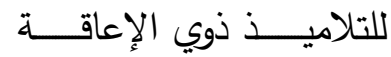

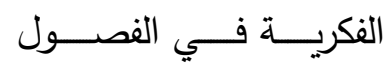

الدراسية.

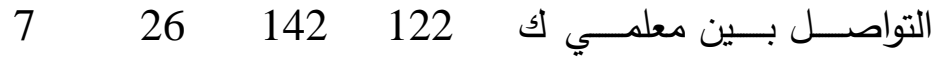

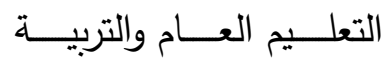

$\begin{array}{lll}7 & 0.72 & 3.28\end{array}$

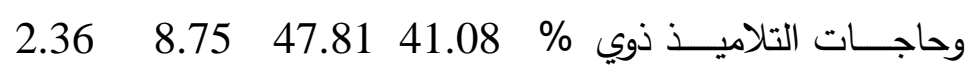

الإعاقــة الفكريـــة يعــز

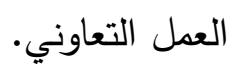
0.71
3.32
المتوسط العام للبُعد

يتضـح مـن الجـدول (Y) آراء أفـراد عينـة الدراسـة مـن معلمسي ومعلمـات تلاميـذ ذوي

الإعاقـة الفكريـة حـول درجـة مـوافقتهم على عبـارات البعد الثاني: العناصـر الأساسية اللازمـة

لإنجاح العمل التعاوني بين المعلمين، فقد كان المتوسط الحسابي العام لهذا البُعد (بس.ب), مما

يعني أن معظم أفراد العينـة من معلمي ومعلمات تلاميذ ذوي الإعاقـة الفكريـة يوافقون بدرجـة

(موافق بشـدة) على بُعـد العناصـر الأساسية اللازمـة لإنجـاح العملـل التعـاوني بـين المعلمـين

بوجه عام.

وعند إلقاء نظرة على الجدول أعـلاه نجد أن العبارة(تقديم الخدمات التربويـة المناسبة

لذوي الإعاقة الفكرية يتطلب الاحترام المتبادل بين معلمي التعليم العام والتربية الخاصـة) احتلت

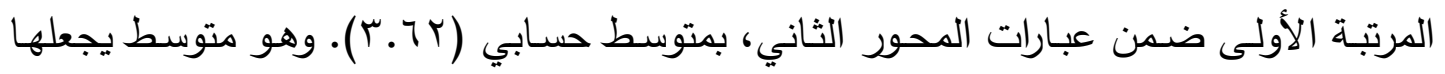




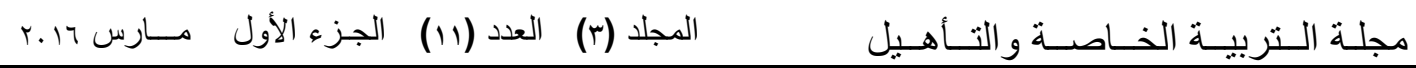

ضمن درجة - موافق بشدة - بالإضـافة إلى ذلك فإنه أعلى متوسط حسابي تم الحصول عليه في أداة الدراسة ككل، وبهذا يمكن القول بأنها أكثر العبارات أهمية بالنسبة لأفراد عينة الدراسـة. ويمكن تفسير هذه النتيجة بأن تكوين العلاقات المهنية بين معلمي التعليم العام والتربية الخاصـة قد يكون أمراً صعباً لبعض المعلمين في البداية، وقد يشعرون بعدم الارتياح، وما لم يشعر كلا الطرفين بـالاحترام المتبـادل بينهما فلن تتحقق استمرارية التعـاون فيمـا بينهما لتقديم الخدمات التربويـة للتلاميـذ ذوي الإعاقـة الفكريـة. ويؤكـد هـذه النتيجـة مـا ورد في دراسـة جـونز وفيـل (Jones \& Vail , 2014)، وبرينكمان وتويفورد (Brinkmann \& Twiford , 2012)، و (رادوفانوفي Radovanovi , 2013 حيث أكدت نتائج تلك الدراسـات على أن مهارة بناء العلاقات الإيجابية بين معلمي التعليم العام والتربية الخاصة والاحترام المتبادل فيما بينهم ضمن فريق عمل يُعد من الأمور التي يجب على المعمين الالتزام بها، وذلك لتعزيز العمل التعاوني

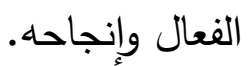

وفي آخر القائمسة ضـمن عبـارات البعد الثاني تأتي العبـارة (يسـهم - اشـتراك معلمي التعليم العام والتربية الخاصـة- في إعداد أهداف الخطة التربويـة الملائمسة للتلاميذ ذوي الإعاقـة الفكريـة) في المرتبـة العاشرة والأخيرة، بمتوسط حسابي (99. ب).ويمكن تفسير هذه النتيجة بأن الخطـة التربويـة الفرديـة للتلاميذ ذوي الإعاقـة الفكريـة تحتـاج لفريق متكامـل يشـترك في إعداد أهدافها وتتفيذها بدقة، وكون معلمي التعليم العام والتربية الخاصـة في معاهد وبرامج دمج ذوي الإعاقـة الفكريـة يفتقدون مشـاركة الفريق متعدد التخصصـات في إعداد الخطـة التربويـة الفرديـة للتلاميذ جـاءت هذه العبارة في المرتبـة الأخيرة. وعلى الرغم من أن هذه العبارة تتذيل قوائم Hunt, et al, ) العبارات في المحور الثاني إلا أن هذه النتيجة تتفق مع دراسة هيونت وآخرون 2003.)،والتي تشير نتائجها إلى أن تتفيذ الخطط التربويـة للتلاميذ ذوي الإعاقات بمشاركة كل من معلمي التعليم العام والتربية الخاصـة ومقدمي الخدمات المسـاندة يسهم في نجاح البرنامج 
التربوي لهؤلاء التلاميذ، وارتفاع مستوى العمل التعاوني بين المعلمين.

البعد الثالث: الكفايات الأساسية لاى معلمي التلاميذ ذوي الإعاقـة الفكريـة لتـأهيلهر

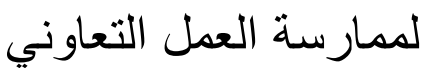

تم استخدام التكرارات، والنسب المئويـة، والمتوسطات الحسابية، والانحرافات المعياريـة، والترتيب للمتوسط الحسابي للتعرف على آراء عينة الدراسة نحو هذا البعد.وقد جاءت النتائج كما هي موضحة في الجدول رقم (r) على النحو التالي:

7.
7.

$\begin{array}{lll}8 & 0.73 & 2.97\end{array}$

بالعمل التعاوني بين معلهي \% $22.921 .2153 .54 \quad 21.96$ التلاميذ ذوي الإعاقة الفكرية.

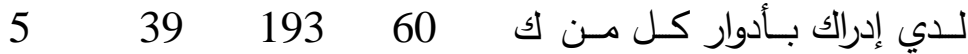
معلمي التلاميذ ذوي الإعاقة

$\begin{array}{lll}5 & 0.63 & 3.04\end{array}$

$1.68 \quad 13.1364 .98 \quad 20.2 \quad$ \% التخطـيط للبرنـامج التربـوي الفردي.

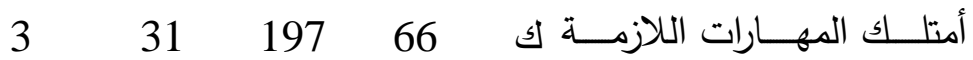

$\begin{array}{lllllcl}3 & 0.60 & 3.1 & 1.01 & 10.44 & 66.33 & 22.2 \\ 2 & & & \end{array}$

للدي معرفـة بطرق التدريس ك5 $54 \quad 45 \quad 45$

$\begin{array}{lll}7 & 0.66 & 3.02\end{array}$

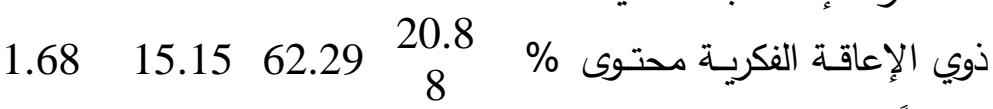
تعليمياً ذا جودة عالية.

$\begin{array}{lllllllll} & 0\end{array}$ 


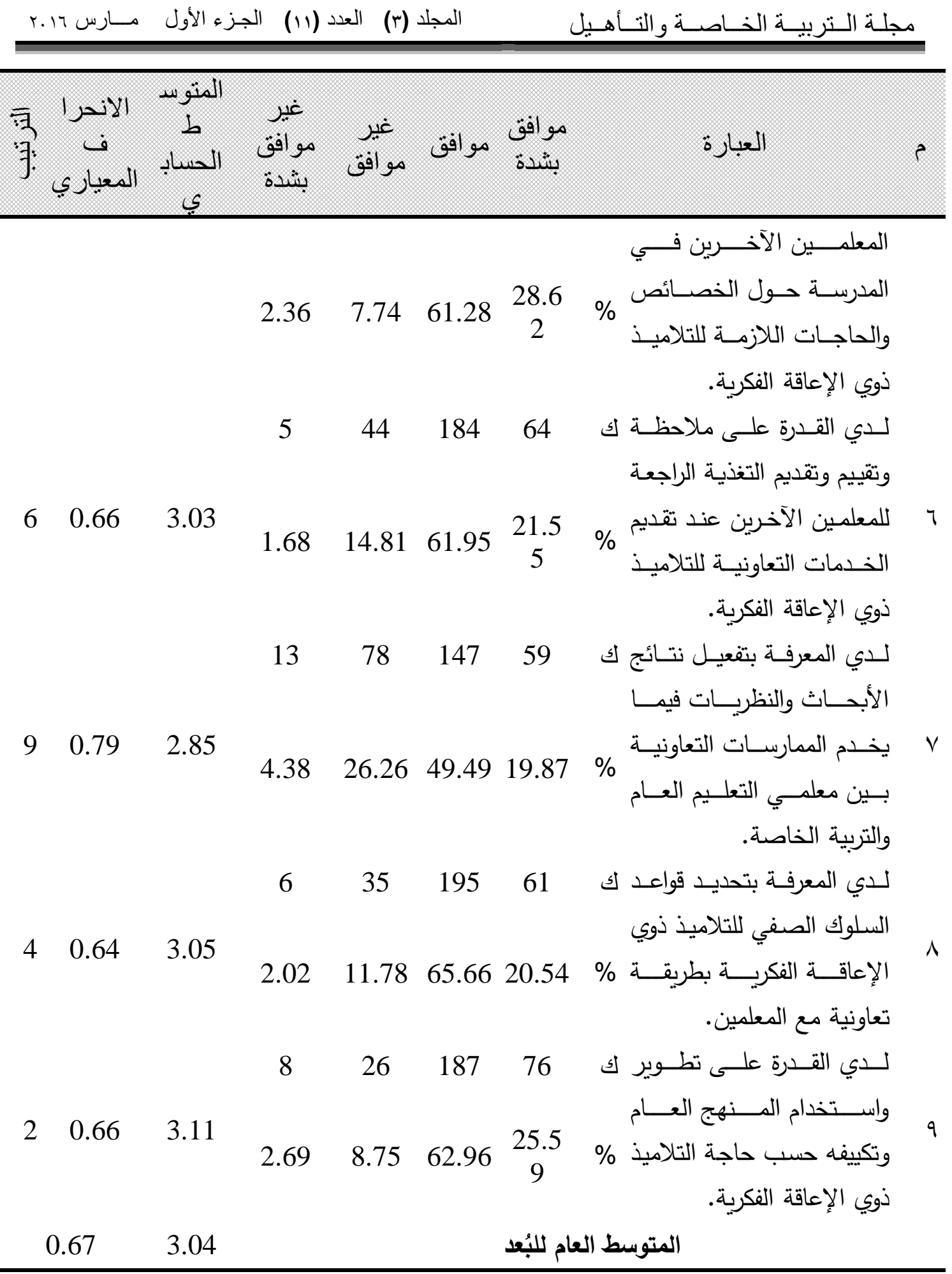

يتضح من الجدول (ع - ب) آراء أفراد عينة الدراسـة من معلمي ومعلمات تلاميذ ذوي الإعاقة الفكريـة حول درجة موافقتهم على عبارات البعد الثالث: الكفايات الأساسية لدى معلمي 
التلاميذ ذوي الإعاقة الفكرية لتأهيلهم لممارسة العمل التعاوني، فقد كان المتوسط الحسابي العام لهذا البُعد (ع . .ب)، مما يعني أن معظم أفراد العينـة من معلمي ومعلمات تلاميذ ذوي الإعاقة الفكريـة يوافقون بدرجة (موافق) على بعد الكفايات الأساسية لدى معلمي التلاميذ ذوي الإعاقـة الفكرية لتأهيلهم لممارسة العمل التعاوني بوجه عام. وبالنظر إلى الجدول رقم (ع - r) نجد العبارة (لاي القدرة على التشاور مـع المعلمين الآخرين في المدرسـة حـول الخصـائص والحاجـات اللازمـة للتلاميذ ذوي الإعاقـة الفكريـة) في

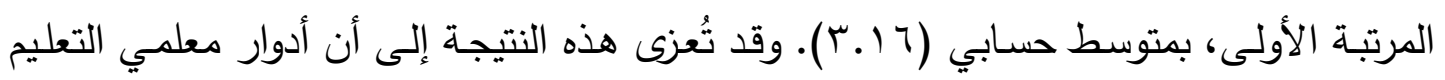
العام والتربية الخاصـة في بيئات الدمج قد توسعت مـع بدء الانتبـاه لمبدأ التفريد في مواجهة حاجـات التلاميذ ذوي الإعاقـة الفكربـة، مدـا يـدعو معلمي التربيـة الخاصـة لتقديم المعلومـات والتشـاور مـع معلمـي التعليم العـام حول التلاميذ ذوي الإعاقـة الفكريـة وخصائصـهم وحاجـاتهم وأهدافهم. كما جاءت هذه النتيجة متوافقة مـع دراسـة (البتال، ع ( ؟)، حيث خلصت نتائجها إلى أن عملية الاستشارة بين معلمي التعليم العام وصعوبات التعلم تمت بمستوى متوسط، وأن معلمي الصعوبات يرون بأنهم يمارسون الاستشارة بمستوى أكبر من معلمي التعليم العام، وذلك لما يملكونه من معلومات أكثر في مجال التخصص. وبـالنظر إلى الجدول رقم (ع - r) نجد عبـارة (لـدي المعرفـة بتفعيل نتائج الأبحاث والنظريات فيما يخدم الممارسات التعاونية بين معلمي التعليم العام والتربية الخاصـة) في المرتبة التاسعة والأخيرة، بمتوسط حسابي (10.1). ويمكن أن يُعزى ذلك إلى كون معلمي التعليم العام والتربية الخاصـة يفتقرون للتنمية المهنية في مجال العمل التعاوني، إما لعدم تأهيلهم في برامج مـا قبل الخدمـة لتفعيل الأبحاث المتعلقة بالممارسـات التعاونيـة، وإمـا لعدم وجود دعم من إدارة المدرسة، وعدم إقامة البرامج التدربية والورش التي تركز في مخرجات التعاون. وقد جاءت هذه النتيجة مخالفة لدراسة جونز وفيل (Jones \& Vail, 2014) التي ورد فيها أن تفعيل نظريات التعاون هو أول العبارات التي يعرفها معلمو التربية الخاصـة قبل الخدمة، ويقومون بتنفيذها في ممارسـاتهم التعاونيــة مـع معلمـي التعلـيم العـام. فـي حـين تتفـق دراســة براونـل وآخـرون 
(Brownell, et al, 2006) الأبحاث الإيجابية المتعلقة بعملية التعاون الفعال سيسهم في تحسين مستوى التعاون المهني بين المعلمين وتطويره، مما يدعم تعليم التلاميذ ذوي الإعاقة.

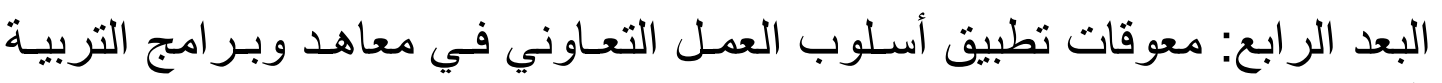

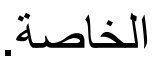
تم استخدام التكرارات، والنسب المئوية، والمتوسطات الحسابية، والانحرافات المعيارية، والترتيب للمتوسط الحسابي للتعرف على آراء عينة الدراسة نحو هذا البعد.وقد جاءت النتائج كما هي موضحة في الجدول رقم (ع) على النحو التالي:

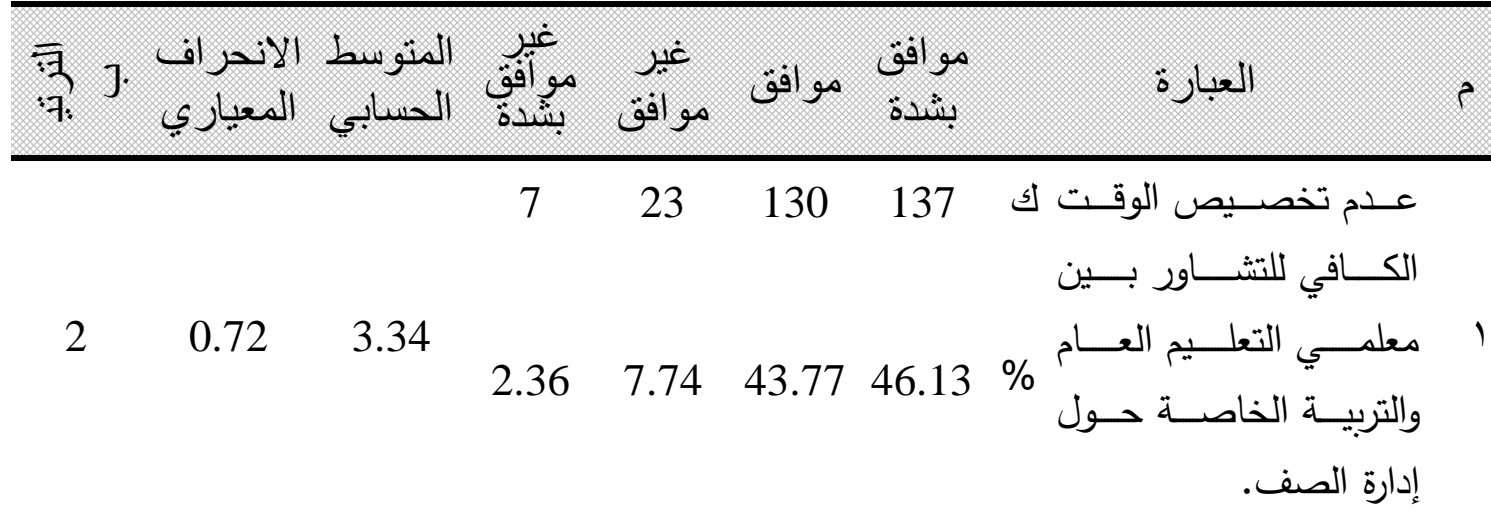

تكليــف إدارة المدرســة ك5 $121 \quad 65 \quad 64 \quad 65$

$\begin{array}{lll}9 & 0.92 & 3.08\end{array}$

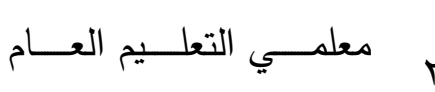
والتزبيـة الخاصـة بنصـاب \% $5.72 \quad 21.5531 .99 \quad 40.74$

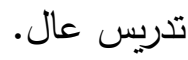

اعتقـاد إدارة المدرسـة بـأن كئ 8

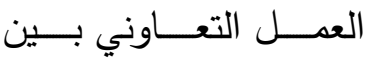

$$
\begin{aligned}
& \text { معلمــي التعلــيم العــام }
\end{aligned}
$$

$\begin{array}{lll}10 & 0.83 & 2.99\end{array}$

$2.69 \quad 26.94 \quad 39.39 \quad 30.98 \%$

والتربية الخاصة لا يحسن

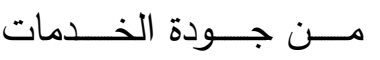

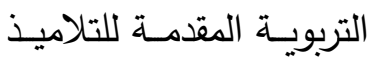
ذوي الإعاقة الفكرية. ؛ ع عدم وضوح الأدوار لكل كلهبه 


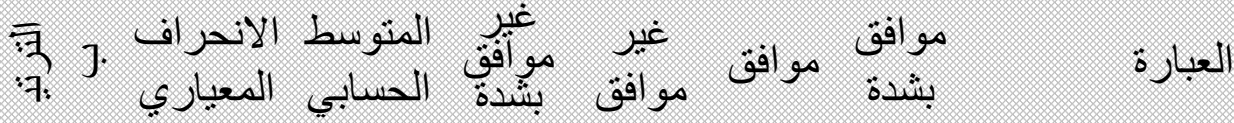

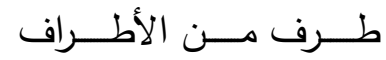$$
\text { العشــاركة فـي أسـلوب الاطبراب }
$$

العمل التعاوني في معاهد \% $\quad 43.1 \quad 4.74 \quad 48.48 \quad 0.67$

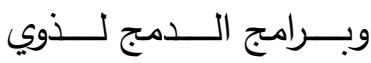

الإعاقة الفكرية.

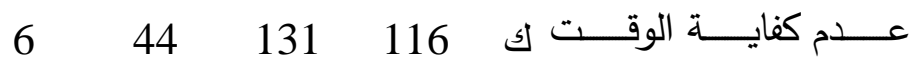
المخصص لمعلمي التعليم

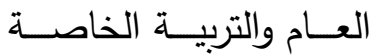

$\begin{array}{lll}8 & 0.76 & 3.2\end{array}$

$2.02 \quad 14.81 \quad 44.11 \quad 39.06 \quad \%$ لاتخـاذ القـرارات المتعلقــة $\circ$ بطــرق التـدريس وتئيـيم

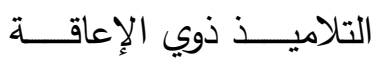
الفكرية.

عـدم تـوافر الإمكانسات ك $150 \quad 31 \quad 314$

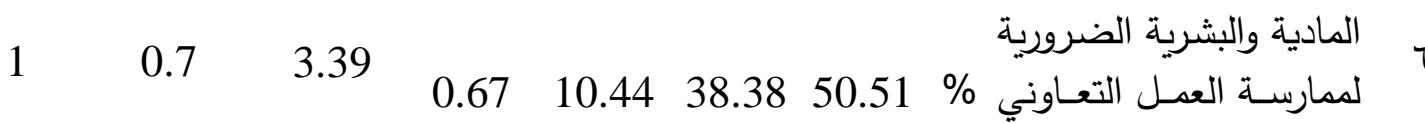

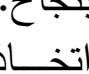

$\begin{array}{lll}4 & 0.76 \quad 3.27\end{array}$

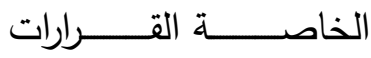

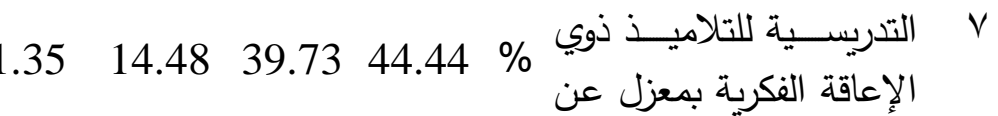

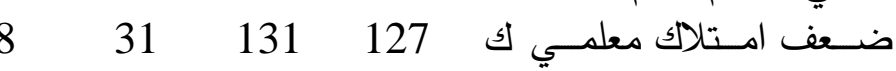

$\begin{array}{lll}4 & 0.75 & 3.27\end{array}$

التواصـل اللازمــة لإنجـاح \% $242.76 \quad 10.44 \quad 44.11 \quad 2$.

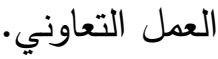

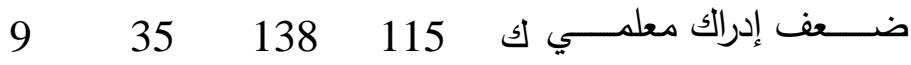

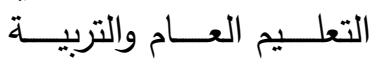

$\begin{array}{lll}7 & 0.77 \quad 3.21\end{array}$ الخاصــة للاخـتلاف بـين

$3.03 \quad 11.7846 .4638 .72 \%$

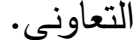
$\begin{array}{llllllll}4 & 0.68 & 3.27 & 2 & 34 & 143 & 118 & 5\end{array}$ 


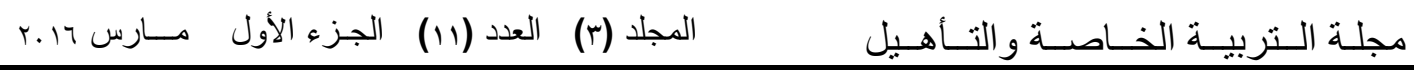

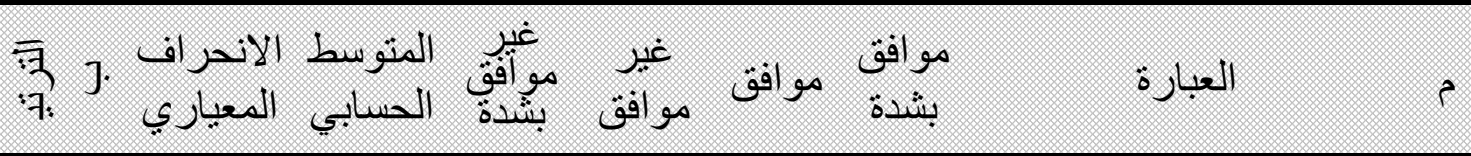
يحملها معلمـوالتعليم العـام

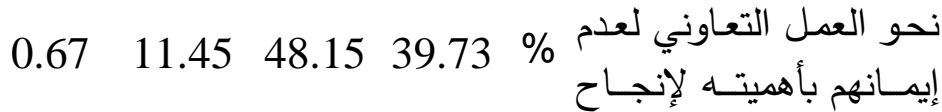
العملية التعليمية. المتوسط العام للبُعد $\quad 3.24 \quad 3$.

يتضـح مـن الجدول (ع) آراء أفـراد عينـة الدراسـة مـن معلمي ومعلمـات تلاميـذ ذوي الإعاقة الفكرية حول درجة موافقته على عبارات المحور الرابع: معوقات تطبيق أسلوب العمل التعـاوني في معاهــ وبـرامج التربيـة الخاصـة، فقــ كـان المتوسـط الحسـابي العـام لهـذا البُعـد

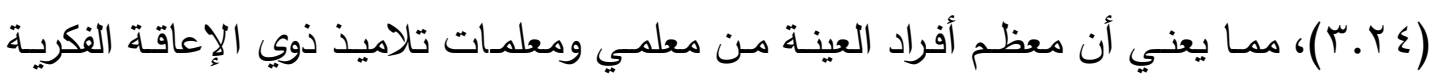
يوافقون بدرجة (موافق) على محور معوقات تطبيق أسلوب العمل التعاوني في معاهد وبرامج التربية الخاصة بوجه عام وبالنظر إلى ترتيب عبارات معوقات تطبيق العمل التعاوني في الجدول السابق يلاحظ أن عبارة (عدم توافر الإمكانـات الماديـة والبشرية الضـرورية لممارسـة العمل التعـاوني بنجـاح) جاءت في المرتبـة الأولى، بمتوسط حسابي (q (ب). وقد تكون هذه النتيجة متوقعة ومنطقيـة، فاستقبال التلاميذ ذوي الإعاقة الفكريـة ومعلميهم المختصين بالتربية الخاصـة في مدارس التعليم العام يتطلب أن تكون تلك المدارس مستعدة مادياً وبشرياً لاستقبالهم، ومن ثم تهيئة الظروف ته المناسبة للتفـاعلات التعاونيـة بين كل مـن معلمي التعليم العـام والتربيـة الخاصـة. وتتفق هذه النتيجة مع ما ورد في دراسة بيلي وآخرون (Bailey, et al ., 1993)، و دامور وموراي (Damore \& murray ， 2009) . حيث توصلت نتائج هذه الدراسات إلى أن عدم توفير الإمكانـات الماديـة والبشـريـة يحد مـن فاعليـة تطبيـق العمل التعـاوني بين المعلمين في البيئة التعليمية التي تضم التلاميذ ذوي الإعاقة الفكرية. 
وفي آخر قائكـة عبـارات البعـد الرابـع جـاءت العبـارة (اعتقـاد إدارة المدرسـة بـأن العمـل

التعاوني بين معلمي التعليم العام والتربية الخاصة لا يحسن من جودة الخدمات التربويـة المقدمة للتلاميذ ذوي الإعاقـة الفكريـة) في المرتبـة العاشـرة والأخيرة، بمتوسط حسـابي (9 . ؟). ويفسر الباحثان حصول هذه العبارة على المرتبـة الأخيرة اعتقاد معلمي التعليم العام والتربيـة الخاصـة بأن هنالك معوقات أكثر منها أهمية من الأولى معالجتها والحد منها،كما قد تُعزى هذه النتيجة إلى كون هؤلاء المعلمين يمتلكون رؤى إيجابيـة وفلسفة مشتركة لمعنى التعـاون، مدـا يجعلهم أشخاصـاً مؤثرين في مديريهم في كل مـا يتعلق بتعليم التلاميذ ذوي الإعاقة. وقد يفسر ذلك أيضـاً بعدم الفهم الكافي لدى مديري المدارس بفوائد العمل التعاوني في رفع تحصسيل هؤلاء التلاميذ. وقد خالفت هذه النتيجة دراسة ريس (Reyes , 2010) التي يشير فيها إلى أن مديري المدارس يؤيدون العملية التعاونية، ويحملون اتجاهات إيجابية نحوها، بينما اتفقت نتيجة الدراسـة الحالية مع دراسة بيلي(Bailey, et al., 1993) التي توصلت إلى أن الاتجاهات السلبية التي يحملها مديرو المدارس حول أسلوب العمل التعاوني بين المعلمين تُعد أحد معوقات تطبيقه. ثانياً: إجابة السؤال الثاني ومناقشة نتائجها: السؤال الثاني: هل هنالك فروق ذات دلالة إحصائية عند مستوى (ه ., • ) في آراء معلمي ومعلمات التلاميذ ذوي الإعاقة الفكرية نحو أسلوب العمـل التعـاوني في البيئة التعليمية بناءً على متغير البيئة التعليمية (معاهد - بر امج دمج) ؟ للإجابة عن السؤال تم استخدام اختبار الفرق بين متوسطي مجتمعين لعينتين مستقلتين لاختبار دلالة الفروق بين آراء معلمي ومعلمات التلاميذ ذوي الإعاقة (Two-sample t-test) الفكريـة نحو أسلوب العمل التعاوني في البيئة التعليمية وفقاً لمتغير البيئة التعليميـة (معاهد برامج دمـ). ويوضـح جدول رقم (0) المتوسط الحسابي، والاتحراف المعياري لاستجابات أفراد الدراسة حول أسلوب العمل التعاوني في البيئة التعليمية بالإضافة إلى نتائج اختبار ت. 


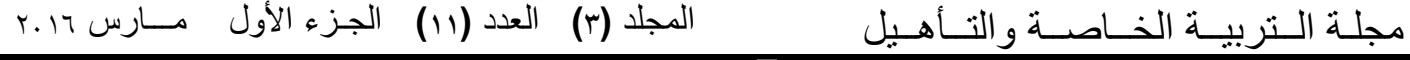


جدول (0) أبرات (0)

در اسة الفروق بين منوسطات استجابات أفراد العينة حول أسلوب العمل التعاوني في البيئة

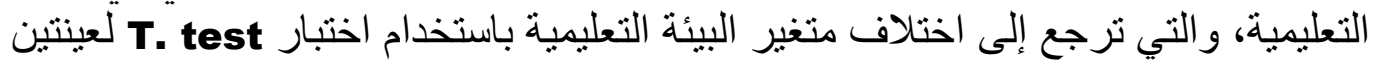
مستقلتين

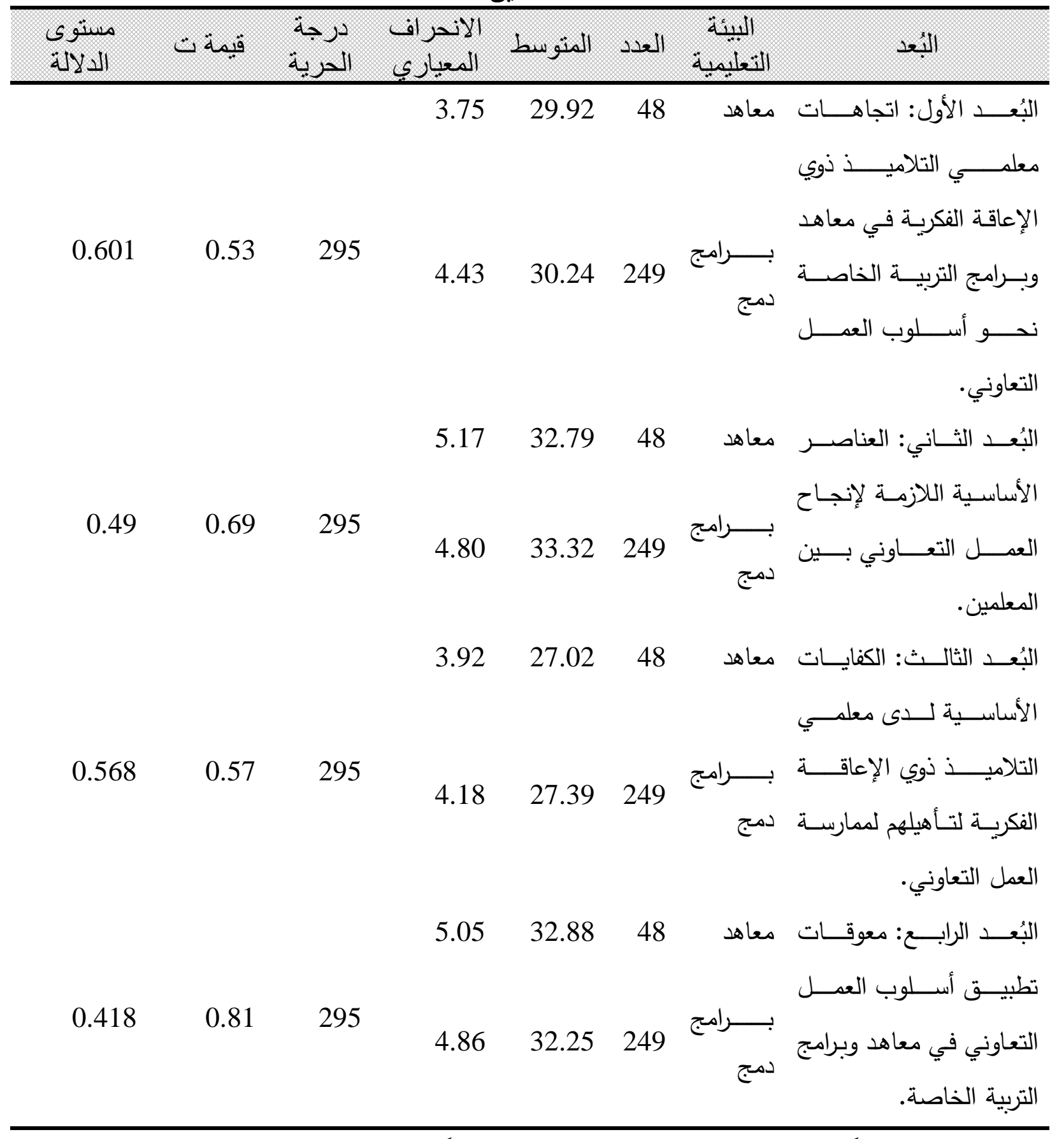

* دالة إحصائياً عند مستوى الالالة (0., .)، *** دالة إحصائياً عند مستوى الدلالة (1., .). 
تشير النتائج إلىى أنـه لا توجد فروق ذات دلالــة إحصـائية في رؤيسة أفراد الدراسـة حول جميع أبعاد أسلوب العمل التعاوني في البيئة التعليميـة ترجع لاختلاف متغير البيئة التعليميـة (معاهد - برامج دمج)، وذلك عند مستوى الدلالة (0 . . )، أي أنه لا يوجد تأثير لمتغير البيئة التعليمية في أي محور من محاور أسلوب الععل التعاوني الأربعة. وقد تُعزى هذه النتيجة إلى استيعاب التلاميذ ذوي الإعاقة الفكرية في برامج الدمج استيعاباً جزئياً بحيث يتلقون تعليمهم في صفوف منفصلة بطريقة مشابهة لما يحدث في معاهد التربية الفكرية. وقد تكون هذه النتيجة متوقعـة، فمن يقوم بالتدريس في فصـول دراسية معزولـة ملحقة ببرامج الدمج كمن يقوم بالتدريس في المعاهد؛ لذلك لن تتأثر استجابات أفراد العينـة بمتغير البيئة التعليمية. وهذه النتيجة جاءت مخالفة لدراسة القريني (10 ـ ب)، حيث أكدت دراسته وجود فروق ذات دلالـة إحصـائية في استجابة أفراد العينـة حول تحديد عوائق ممارسـة العمل التعاوني بين المعلمين وفقاً لمتغير الموضـع التعليمي لصالح الذين يقومون بالتدريس في فصول دمج التربية الخاصة الملحقة بالمدارس العادية. ثالثاً إجابة السؤال الثالث ومناقشاة نتائجه:

السؤال الثالث: هل هنالك فروق ذات دلالة إحصائية عند مستوى (0 . . • ) في آراء

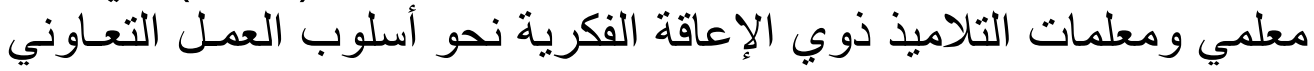
في البيئة التعليمبة بناءً على متغير الجنس (ذكور - إناث) ؟ للإجابة عن السؤال تم استخدام اختبار الفرق بين متوسطي مجتمعين لعينتين مستقلتين لاختبار دلالة الفروق بين آراء معلمي ومعلمات التلاميذ ذوي الإعاقة (Two-sample t-test) الفكريـة نحو أسلوب العمل التعاوني في البيئة التعليميـة وفقاً لمتغير الجنس (ذكور - إنـاث). ويوضح جدول رقم (ع ا V) المتوسط الحسابي، والانحراف المعياري لإجابات أفراد الدراسـة حول أسلوب العمل التعاوني في البيئة التعليمية، بالإضافة إلى نتائج اختبار ت. 


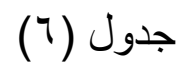

در اسة الفروق بين منوسطات استجابات أفراد العينة حول أسلوب العمل العبات التعاوني في البيئة التعليمية، و التي ترجع إلى اختلاف متغير الجنس باستخدام اختبار T. test لعينتين مستقلتين

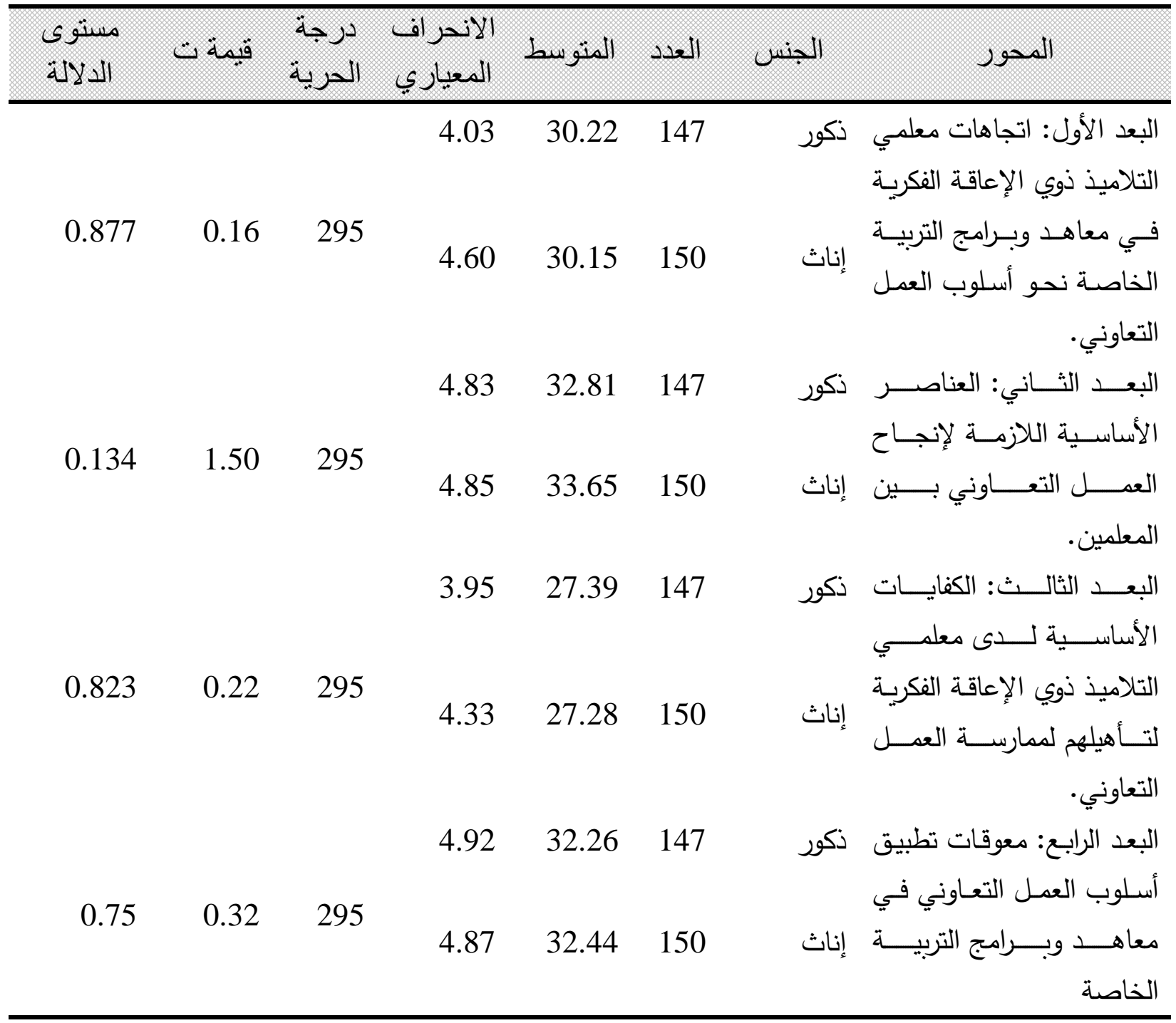

* دالة إحصائياً عند مستوى الد لالة (ه ...)، ** دالة إحصائياً عذ مستوى الدلالة (1 ..).

تشير النتائج إلى أنـه لا توجد فروق ذات دلالـة إحصائية في رؤيـة أفراد الدراسـة حول

جميع محاور أسلوب العمل التعاوني في البيئة التعليمية ترجع لاختلاف متغير الجنس (ذكور ،

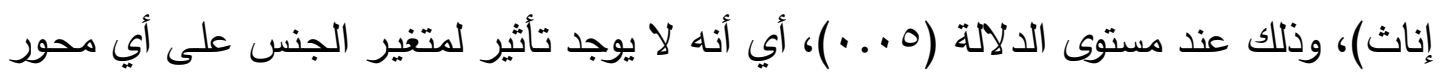
من محاور أسلوب العمل التعاوني الأربعة. 
ويمكن أن تُعزى هذه النتيجـة باتفـاق جميع معلمي التلاميذ ذوي الإعاقـة الفكريـة على

اختلاف جنسهم إلى أهمية أسلوب العمل التعاوني، وضـرورة توافر العناصر الأساسية اللازمـة لنجاحـه، وحاجـة معلمي التعليم العـام والتربيـة الخاصـة ككل للكفايـات المهنيـة، ورفـع مستواهم المهني، ومن ثم مواجهة المعوقات التي تحد من تطبيق العمل التعاوني، مما يعكس حاجتهم الماسـة لجميـع مـا ورد في عبـارات الإسـتبانة بأبعادهـا الأربعـة، بصـرف النظـر عـن جنس المشـاركين في الدراسـة، وقد تفسر هذه النتيجة بإدراك معلمي التلاميذ ذوي الإعاقة الفكريـة على اختلاف جنسهم - أن العمل التعاوني يحظى بأهمية كبرى باعتباره أحد الأسـاليب الحديثة في تقديم الخدمات التربوية للتلاميذ ذوي الإعاقة الفكرية, والذي بدوره يمكن أن يُحسن من جودة تلك الخدمات . وتتفق هذه النتيجة مع نتيجة دراسة (طاهر وأشكناني، 9 . . ب) التي تشير إلى عدم وجود فروق ذات دلالة إحصائية بين حاجة كل من معلمي التربية الخاصـة للعمل التعاوني في برامج التربية الخاصة وفقاً لمتغير الجنس. وتختلف مع دراسـة ديوك (Duke, 2004) التي وُجد فيها فروق ذات دلالــة إحصـائية في عمليـة التعـاون بـين معلمي التعليم العـام والتربيـة الخاصــة بنـاءً على متغير الجنس.

السؤال الرابع: هل هنالك فروق ذات دلالة إحصائية عند مستوى (0 . . • ) في آراء

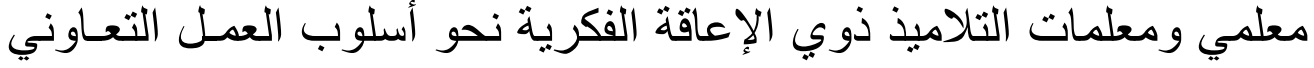

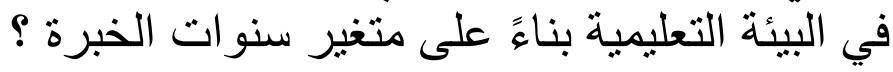
للإجابـة عـن السؤال السـابق تم اسـتخدام تحليـل التبـاين الأحسادي ( One -way) ANOVA ويوضـح جـدول رقـ (V) نتائج تحليل التبـاين لاختبـار دلالـة الفـروق بـين أفراد الدراسـة في آرائهم نحـو أسلوب العمل التعـاوني في البيئة التعليميـة بنـاءً على متغير سنوات الخبرة. 


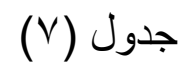

نتائج اختبار تحليل التباين الأحادي (ANOVA) للفروق بين استجابات أفراد العينة حول

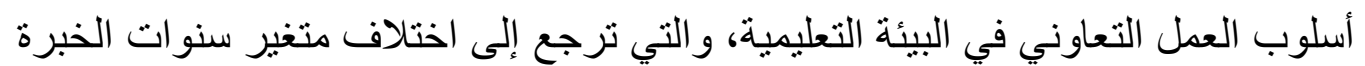

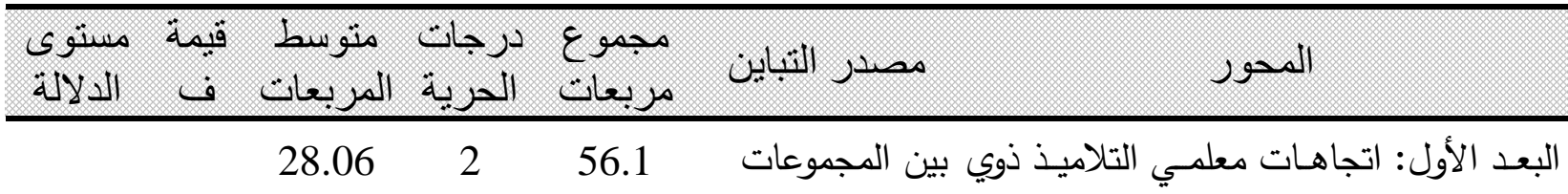

$0.223 \quad 1.51$

داخل المجموعات $\quad 29474.7 \quad 29.6$ الإعاقـة الفكريـة فـي معاهـد وبـرامج التربيـة الخاصة نحو أسلوب العمل التعاوني.

$0.155 \quad 1.87$

البعـــ الثـاني: العناصـر الأساسية اللازمــة بين المجموعات $\quad 87.8 \quad 23.89$ لإنجاح العمل التعاوني بين الدعلمين. $\quad 23883.7 \quad 294 \quad 2$ البعد الثالث: الكفايات الأساسية لدى معلمي بين الدجموعات $\quad 64.8 \quad 2 \quad 32.41 \quad 2$ $0.151 \quad 1.91$

داخل المجموعات $5001.2 \quad 294 \quad$

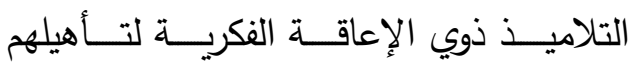
لممارسة العمل التعاوني.

البعد الرابع: معوقات تطبيق أسلوب العـل بين المجموعات $\quad 69.7 \quad 24.83 \quad 2$

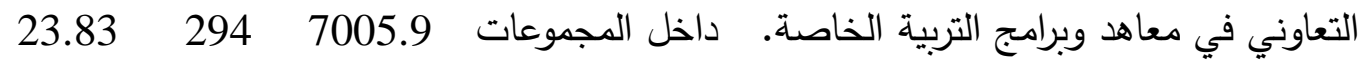

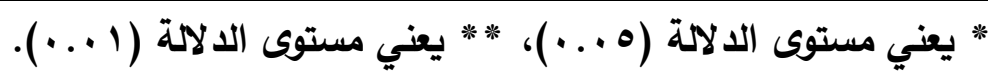

تشير النتائج إلى أنه لا توجد فروق ذات دلالة إحصائية حول أي محاور أسلوب العمل التعاوني في البيئة التعليمية ترجع لاختلاف متغير سنوات الخبرة (أقل من خمس سنوات - من

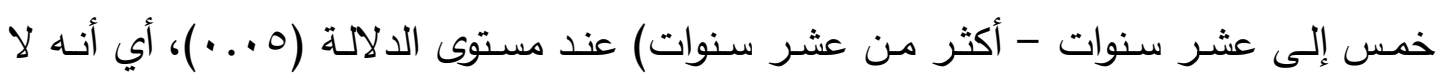
يوجد تأثير لمتغير سنوات الخبرة حول أي محور من محاور أسلوب العمل التعاوني في البيئة

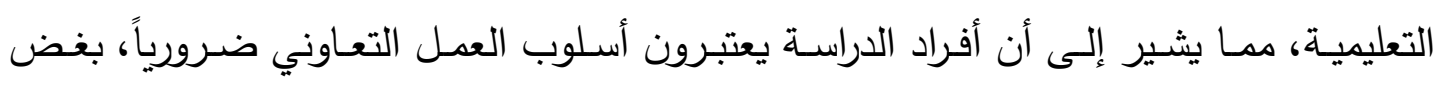
النظر عن عدد سنوات خبرتهم، وقد تُعسر هذه النتيجة بعدم تطوير برامج إعداد معلمي التعليم العام وتحسينها، فهي لم تكن على مستوى عال يمكنهم من ممارسة أسلوب العمل التعاوني،

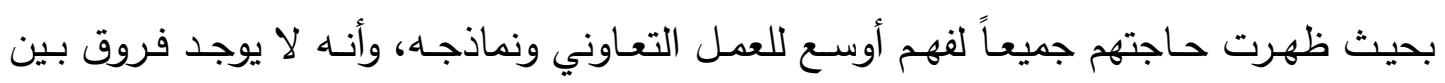
المعلمين في حاجتهم المحسوسـة، ورغبتهم في العمل التعاوني، بصـرف النظر عن سنوات 


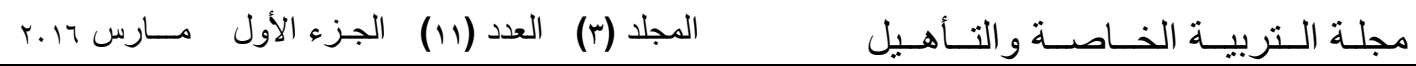

الخبرة التي مروا بها، وقد تعزى هذه النتيجـة أيضـاً إلى تقارب سنوات الخبرة لمعلمي التلاميذ ذوي الإعاقة الفكرية في مدينة الرياض. حيث أن معلمي هؤلاء التلاميذ الذين خبرتهم من (0-

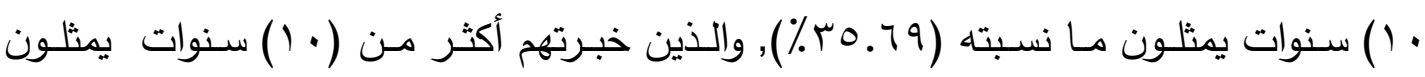

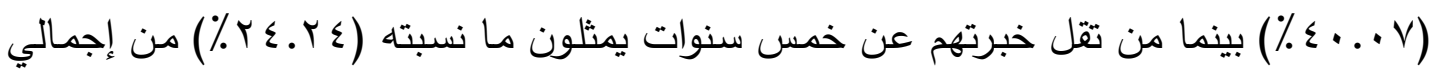

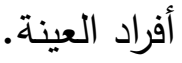

وتتفق هذه النتيجة مع نتائج الدراسـات السابقة في أنه لا يوجد أثر لمتغير سنوات الخبرة

حول مستوى ممارسة أسلوب العمل التعاوني بين معلمي التربية الخاصسة ومعلمي التعليم العام،

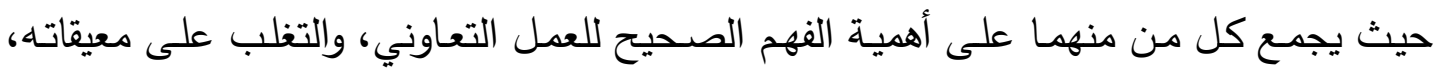
كدراسة (البتال، ع ا • (ب)، ودراسة بيلي (Bailey, et al., 1993).

السؤال الخامس: هل هناك فروق ذات دلالـة إحصائية عند مستوى (ه . . ) في آراء معلمي ومعلمات التلاميذ ذوي الإعاقة الفكرية نحو أسلوب العمل التعاوني في البيئة التعليميـة بناءً على متغير التخصص (معلم تربية فكرية - معلم تعليم عام) ؟ للإجابة عن السؤال تم استخدام اختبار الفرق بين متوسطي مجتمعين لعينتين مستقلتين لاختبار دلالة الفروق بين آراء معلمي ومعلمات التلاميذ ذوي الإعاقة (Two-sample t-test) الفكريـة نحو أسـلوب العمل التعـاوني في البيئة التعليميـة وفقاً لمتغيـر التخصص (معلم تربيـة فكريـة - معلم تعليم عام)،ويوضـح جدول رقم (ع - 9) المتوسط الحسابي والانحراف المعياري لإجابات أفراد الدراسـة حول أسلوب العمل التعـاوني في البيئة التعليميـة، بالإضـافة إلى نتائج

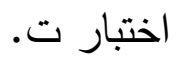


جدول (^)

در اسة الفروق بين متوسطات استجابات أفراد العينة حول أسلوب العمل التعاوني في البيئة التعليمية، و التي ترجع إلى اختلاف متغير تصنيف المعلم باستخدام اختبار T. test لعينتين مسنقلتين

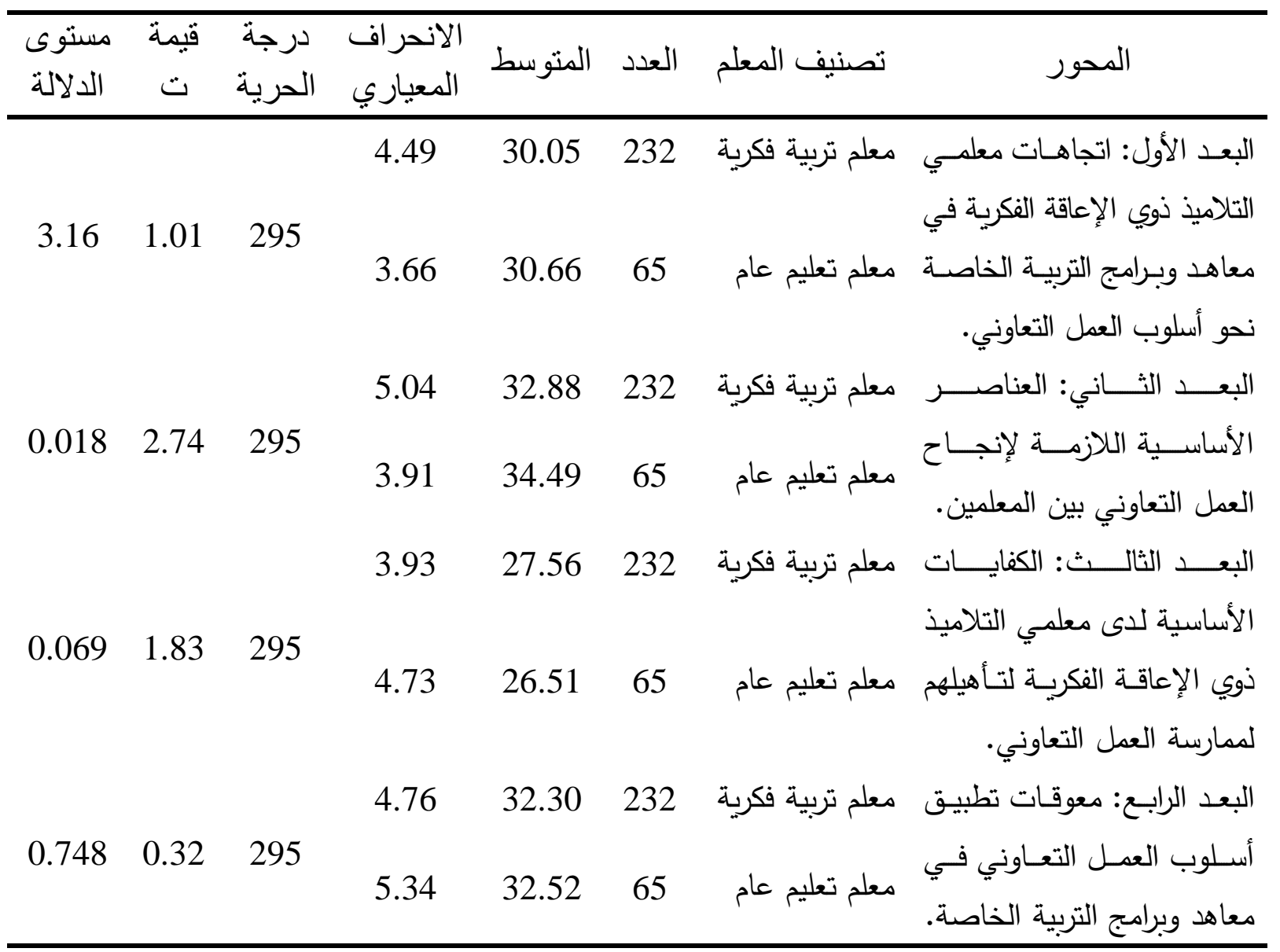

* دالة إحصائياً عند مستوى الد لالة (0 . . )، ** * دالة إحصائياً عند مستوى الدلالة (1 ...).

تشير النتائج إلى أنها توجد فروق ذات دلالة إحصائية عند مستوى دلالة (0 . • ) حول بعد العناصر الأساسية اللازمـة لإنجاح العمل التعاوني بين المعلمين فقط من محاور أسلوب العمل التعاوني في البيئة التعليمية ترجع لاختلاف تخصص المعلم (معلم تربية فكريـة - معلم تعليم عـام) لصـالح المتوسط الحسـابي لمجموعـة أفراد العينـة مـن معلمي التعليم العـام، أي أن مجموعة أفراد العينة من معلمي التعليم العام أكثر موافقة على محور العناصر الأساسية اللازمة لإنجاح العمل التعاوني بين المعلمين من مجموعة أفراد العينة من معلمي التربية الفكرية. 


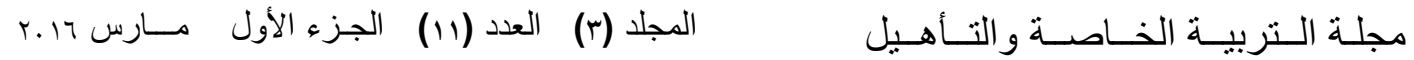

وقد يعود السبب في ذلك إلى أن معلمي التربية الفكريـة بحكم طبيعة تخصصهم لديهم من المعلومات عن التلاميذ ذوي الإعاقة الفكرية، وأساليب تقديم الخدمات التربويـة الملائمسة لهم التي تجعلهم يعملون بمعزل عن معلمي التعليم العام بحجة أنهم لم يتلقوا التأهيل الكافي للتعامل مع ذوي الإعاقـة الفكريـة، لذلك نجد آراءهـ أكثر موافقـة لمعرفـة العناصـر اللازمـة لنجـاح العمـل التعاوني .وهذه النتيجة تتفق مع دراسة بيلي (Bailey ,et al ., 1993)، حيث تثبت نتائجها أن عملية التعاون بين المعلمين تتفاوت نسب وجودها، وتختلف حسب تخصص المشـاركين في Gregory, الدراسة (معلم تعليم عام، تربية خاصدة). وخالفت هذه النتيجة دراسة جريقوري 2009) التي تؤكد عدم وجود فروق بين معلمي التعليم العـام والتربيـة الخاصـة حول ممارسـة العمـل التعـاوني لتقـديم الخــدمات التربويـة للتلاميـذ ذوي الإعاقـة، ودراسـة دامـور ومـوراي (Damore \& murray, 2009) الإيجابية أكبر حول العمل التعاوني والممارسات القائمة عليه، مقارنـة باتجاهات معلمي التعليم العام. 


$$
\text { قـائدسـة المــر/جـع }
$$

$$
\text { أولًا: المر/جع العربية: }
$$

الأمانـة العامة للتربية الخاصـة (YY ( إهـ). القواعد التظيمية لمعاهد وبرامج التربية الخاصـة التابعة لوزارة المعارف سابقًا، الرياض، مطابع الأمانة العامة للتربية الخاصة

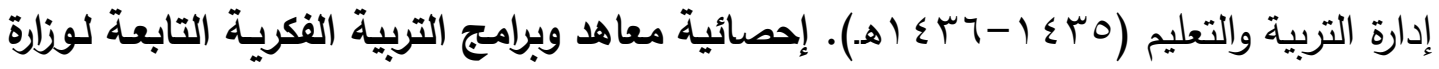
التعليم، الرياض، شعبة نظم المعلومات والدعم الفني. البتال، زيد (ع ا • ب). مستوى الممارسة لعملية: الاستشارة والعمل الجماعي بين معلمي التلاميذ ذوي صـوبات التعلم ونظرائهم معلمي الفصـول العاديـة في المرحلـة الابتدائيـة بمدينـة

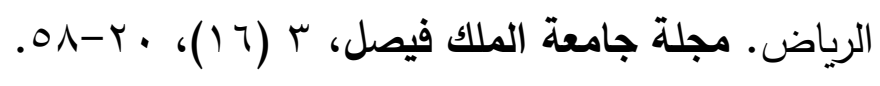

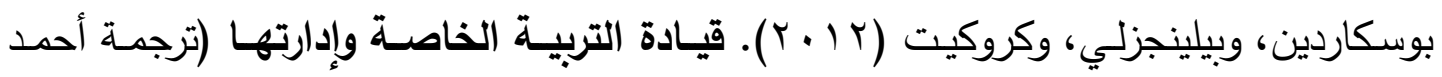
التميمسي). الريـاض، دار جامعـة الملك سـود للنشـر • (العمـل الأصـلي نشـر في عـام

$$
\cdot(r \cdot) \varepsilon
$$

التميمي، أحمد عبدالعزيز (r ( • ب). أبرز الممارسات العالميـة في إعداد وتأهيل العاملين في مجال التدخل المبكر، بحث مقدم في مؤتمر "التوجهات الحديثة في التربية الخاصـة"

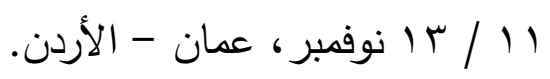

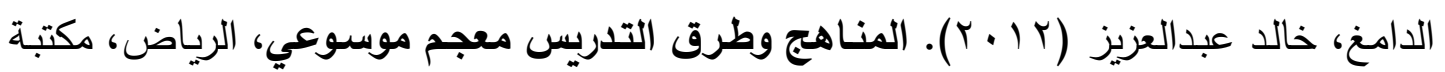
الملك فهد الوطنية.

الزبـون، محمد سـليم ودورسـوه، أمـل محمد (ب ( ب). آراء معلمي المـدارس الاستكثـافية في برنـامج "نحو اتجاهـات مدرسية جديدة" مجلـة الجامعـة الإسـلامية للاراسـات التربويـة

$$
\text { والنفسية، الأردن، Y ( ) ( ) (V). }
$$




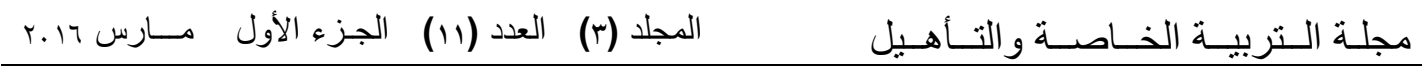

السرطاوي، زيدان والثـخص، عبدالعزيز والعبد الجبار ، عبدالعزيز ( . . ب). الـدمج الثــامل لذوي الإعاقة مفهومهه وخلفيته النظريـة. الإمـارات العربية المتحدة، العين، دار الكتاب

الجامعي

طاهر ، حسين واشكناني، أحمد (9 r). مدى التفاعل بين المعلم والاختصاصسي النفسي في

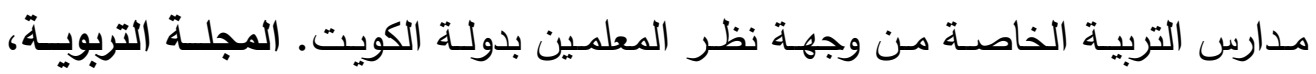

$$
\text { الكويت، r ( }
$$

عبيدات، ذوقان وعبدالحق، كايد، وعدس، عبدالرحمن (V . . r) البحث العلمي مفهومـه أدواته وأساليبه. عمان، دار الفكر .

القريطي، عبد المطلب أمين (11 (ب). سـيكولوجية ذوي الإعاقـة وتـربيتهم، القـاهرة، مكتبـة الأنجلو المصرية.

القريني، تركي (0 1 • (Y). عوائق ممارسـة العمل الجماعي بين معلمي التعليم العـام ومعلمي التربية الخاصـة في تعليم التلاميذ ذوي الإعاقة في المدارس العادية. المجلـة التربويـة،

$$
\text { كلية التربية - جامعة عين شمس وس، (ع). }
$$

أبو قلة، السيد عبد الحميد (V) . . r). التوجهات المعاصرة في إعداد معلـم التربية الخاصـة، مصر -القاهرة، زهراء الشرق.

المبرز ، إبراهيم (· ( • ( ). التـدريس النـاجع لـذوي الإعاقـة الفكريـة، (طب)، الريـاض، مطـابع الشريف.

أبو نيان، إبراهيم سـعد (V . . r). الاستشـارة والعمل الجمـاعي كأحد الأسـاليب التربويـة لتقديم خدمات صعوبات التعليم في المرحلة المتوسطة والثانويـة، مجلة كلية التربية بالزقازيق

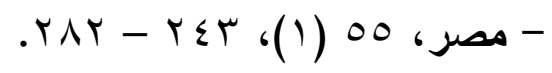

الوابلي، عبدالله محمد (799 ( ) ). واقع الخدمات المساندة من وجهة نظر العاملين في معاهد التربية الفكريـة في المملكة العربية السعودية، مجلـة كليـة التربية، ، ب (Y)، الريـاض، 
American Association On Intellectual \& Developmental Disabilities (AAIDD) Retrieved October 24, 2014 http://www.aaidd.org

Brinkmann, J.\& Twiford, T. (2012). Voices from the field: Skill sets needed for effective collaboration \& co-teaching. International Journal of Educational Leadership Preparation, 7(3), 13.

Brownell, M. T., Adams, A., Sindelar, P., Waldron, N.\& Vanhover, S. (2006). Learning from collaboration: The role of teacher qualities. Exceptional Children, 72 (2)169-185.

Blanton, L. P.\& Pugach, M. C. (June, 2007). Collaborative programs in general \& special teacher education: An action guide for higher education \& state policy makers. Washington, DC: Council of Chief State School Officers.

Bailey,C. R. (1993). An investigation of resistance to teacher collaboration--knowledge with which to "fix what's broken." . Retrieved February 26، 2015 from http://search.proquest.com/ docview/62774276?accountid=44936

Carter, N., Prater, M. A., Jackson, A.\& Marchant, M. (2009). Educators' perceptions of collaborative planning processes for students with disabilities. Preventing School Failure, 54(1)60-70.

Cookson, P. W. (2005). Challengs of isolation. Teaching Pre K-8, 35 (2) 14-16.

Damore, S. J.\& Murray,C. (2009). Urban elementary school teachers' perspectives regarding collaborative teaching practices.Remedial \& Special Education,30(4)234-244 
Duke,T. S. (2004). Problematizing collaboration: A critical review of the empirical literature on teaching teams Allen Press,810 E. 10th St.,Lawrence, KS 66044. Retrieved from http://search.proquest .com/docview/62119797?accountid=44936.

Friend,M.,Cook, L.,Hurley-Chamberlain,D. ‘\& Shamberger,C. (2010). Co-teaching: An illustration of the complexity of collaboration in special education. Journal of Educational \& Psychological Consultation, 20(1)9-27.

Garderen, D., Stormont, M. ،\& Goel, N. (2012). Collaboration between general \& special educators \& student outcomes: A need for more research. Psychology in the Schools, 49(5)483-497

Gerry, N(2013). Supporting Co-Teaching Teams in High Schools: Twenty Research-Based Practices. American Secondary Education, v42 n1 p73-83.

Gregory, S. W.(2009) .Perceptions among special education teachers, general education teachers \&\& school administrators relative to collaborative teacher practices \& definition of collaboration in high schools in an urban school district. , 142.

Griffin,C. C.,Jones,H. A.,\& Kilgore,K. L. (2007). The unintended side effects of including students with learning disabilities for teacher educators. Journal of Learning Disabilities , 14(3) , 195-204

Hernandez,S. J. (2013). Collaboration in special education: Its history, evolution,\& critical factors necessary for successful implementation Retrieved March27,2015from: http://search.proquest.com/ docview/1413415125? accountid=44936 
Hines,J. T. (2008). Making collaboration work in inclusive high school classrooms.Intervention In School \& Clinic,43(5), 277-282.

Holdheide,L. R.,\& Reschly,D. J. (2008). Teacher preparation to deliver inclusive services to students with disabilities: TQ connection issue paper.National Comprehensive Center for Teacher Quality. Retrieved January 27 , 2015 from: http://search.proquest.com/ docview/1413416097? accountid=44936

IDEIA (Individuals with Disabilities Education Improvement Act of 2004). (2004). Personnel development to improve services\& results for children with disabilities, Sec 662, 132. Retrieved April 24, 2015, from http://thomas.loc.gov/cgi-bin/query/z?c108:H.R.1350:

Jones,B.,\& Vail,C. O. (2014). Preparing special educators for collaboration in the classroom: Pre-service teachers' beliefs \& perspectives. International Journal of Special Education , 29(1),76-86.

Karge,B. D.,McClure,M.,\& Patton,P. (1995). The success of collaboration resource programs for students with disabilities in grades 6 through 8. Remedial \& Special Education , 16(2): 79-89.

Ledoux,Cathy.,Graves,Shanna \& Burt,Winona.(2012). Meeting the Needs of Special Education Students in Inclusion Classrooms . Journal of the American academy of special education professionals.20-33.

Madigan,J. C.,\& Schroth-Cavataio,G. (2011). Building collaborative partnership.Principal Leadership , 12(3), 26-30.

McLaren,E.,Bausch,M.,\& Ault,M. (2007). Collaboration Strategies Reported by Teachers Providing Assistive Technology Services. Journal Of Special Education Technology, 22(4), 16-29. 
Niles,W. J.,\& Marcellino,P. A. (2004). Needs based negotiation: A promising practice in school collaboration. Teacher Education \& Special Education, 27(4),419-432

Overall,P. (2005). Toward a theory of collaboration for teachers \& librarians. school Library Media Research,8,36. Retrieved April 24 , 2015 fromhttp://search.proquest.com/docview/1023530857? accountid $=44936$

Radovanovic,B,Radiæ-Šestic,V,Milanovic-

Dobrota,Slavkovic,ALangoviæ-Milicvic. (2013).General \& special education teachers' relations within teamwork in inclusive education: socio-demographic characteristics,South African Journal of Education; 2013; 33(3) .

Rao,S.,Hawkins,R. O.,\& Tan,C. (2011). A Practitioner's guide to consultation \& problem solving in inclusive settings. Teaching Exceptional Children,44(1), 18-26.

Reyes,E. R . (2010) A descriptive study of collaboration in general \& special education in two school districts: Perceptions of the principals \& teachers toward sustainability.

Santangelo,T. (2009). Collaborative problem solving effectively implemented,but not sustained: A case for aligning the sun,the moon,\& the stars. Exceptional Children,75(2), 185.

Sharpe,M. N.,\& Hawes,M. E. (2003). Collaboration between general \& special education : Making it work. issue brief National Center on Secondary Education \& Transition

Smith,R.,\& Leonard,P. (2005). Collaboration for inclusion: Practitioner perspectives. Equity \& Excellence in Education,38(4), 269-279. 
Tannock,M. T. (2009). Tangible \& intabible elements of collaborative teaching.Intervention in School \& Clinic,44(3), 173-178.

aldron,N. L.,\& McLeskey,J. (2010). Establishing a collaborative school culture through comprehensive school reform. Journal of Educational \& Psychological Consultation, 20(1),58-74.

Wallace,T.,\&erson,A. R.,\& Bartholomay,T. (2002). Collaboration: An element associated with the success of four inclusive high schools. Journal of Educa-tional \& Psychological Consultation , 13,349-38

Worrell,J. L. (2008). How secondary schools can avoid the seven deadly school "sins" of inclusion.American Seconday Education,36(2),4356.

Wiggins,K. C.,\& Damore,S. J. (2006). "Survivors" or "friends"? A framework for assessing effective collaboration. Teaching Exceptional Children,38(5),49-56.

Winn,J.,\& Blanton,L. (2005). The call for collaboration in teacher education. Focus on Exceptional Children,38(2) , 1-10. 